\title{
Therapeutic Application of Diverse Marine-derived Natural Products in Cancer Therapy
}

\author{
CHUL WON YUN ${ }^{1}$, HYUNG JOO KIM ${ }^{1}$ and SANG HUN LEE ${ }^{1,2}$ \\ ${ }^{1}$ Medical Science Research Institute, Soonchunhyang University Seoul Hospital, Seoul, Republic of Korea; \\ ${ }^{2}$ Department of Biochemistry, Soonchunhyang University College of Medicine, Cheonan, Republic of Korea
}

\begin{abstract}
Natural products (NPs) are useful sources of bioactive compounds and play important roles in the development and discovery of new drugs for diverse human diseases. Most natural products originate from terrestrial species, but diverse marine organisms are another source of new agents for cancer therapy. Natural products derived from marine organisms show diverse pharmacological activities via bioactive secondary metabolites. They regulate biological activities, such as cell proliferation, cell viability, induction of ROS production, ER stress, and apoptosis via modulation of cellular mechanisms in many cancers. Many natural products isolated from marine species require further study to elucidate the efficacy of their biological activity and anticancer effects. In this review, we summarize the biological properties and anticancer effects of diverse natural products extracted from marine organisms and their roles in tumor therapy.
\end{abstract}

Cancer is one of the leading causes of death and an economic burden worldwide (1). Cancer involves an abnormal proliferation of cells and tissues, and is affected by various risk factors such as age, diet, genetics, and environmental factors $(2,3)$. It is also caused by the mutation of several cancer-related genes called tumor suppressors and oncogenes (4). Cancer also presents the ability of metastasis and recurrence, which are difficult to treat (5). Although conventional anticancer therapy includes both chemotherapy to induce apoptosis of target cancer cells and surgical

This article is freely accessible online.

Correspondence to: Sang Hun Lee, Ph.D., Medical Science Research Institute, Soonchunhyang University Seoul Hospital, Seoul, Korea and Departments of Biochemistry, Soonchunhyang University College of Medicine, Cheonan, Republic of Korea. Tel: +82 27099029, e-mail: ykckss1114@nate.com,jhlee0407@sch.ac.kr

Key Words: Marine natural products, cancer, anticancer activity, review. therapy to remove tumors, these methods are limited by issues of therapeutic efficacy, safety, and side effects. Thus, it is necessary to develop novel strategies for cancer therapy, and natural products (NPs) are a promising source for novel drug development because they show diverse biological activities and anticancer effects via inhibition of tumor growth by interacting with several signaling pathways $(6,7)$.

NPs have been a useful source of bioactive compounds and play an important role in the discovery and development of drugs. Most NPs, originated from terrestrial microbes, fungi, and plants, have been discovered to possess many pharmacologically active factors and used to treat several human diseases. Some of these are utilized as clinically valuable drugs for anticancer therapy (8-10). However, marine organisms have recently attracted substantial attention because $70 \%$ of the earth is covered by water, representing $95 \%$ of biodiversity (1113). NPs derived from marine organisms have been researched for novel bioactive secondary metabolites due to their diverse pharmacological activities. Marine environments are estimated to harbor more than one million species and one billion different types of marine microbes (14). Today, around 28,000 new compounds isolated from marine species, such as algae, seaweed, sponges, and starfish, have been reported, and this species diversity provides a diverse array of secondary metabolic products $(15,16)$.

In this review, we present NPs derived from marine environments, and summarize their anticancer activities, such as inhibition of tumor growth, cancer drug resistance, and metastasis. Finally, we discuss NPs as therapeutic agents for safe and efficient cancer treatment.

\section{The Potential Therapeutic Effects of Marine Seaweed- and Algae-derived Natural Products for Cancer Therapy}

Marine algae or seaweeds are plants living in marine or brackish water and are autotrophic organisms that contain chlorophyll for oxygenic photosynthesis $(17,18)$. These 
plants demonstrate metabolic plasticity and produce several compounds that can be used for drug development (19). Moreover, they can be easily cultivated in bioreactors to obtain high amounts of biomass and provide diverse marine compounds for drug discovery (20).

Inhibition of cancer cell proliferation and survival by Carotenoids derived from marine seaweed and algae. Chlorella species can be used to extract diverse carotenoids, such as lutein, $\beta$-carotene, zeaxanthin, and astaxanthin. One study showed that carotenoids extracted from the green algae Chlorella ellipsoidea and $C$. vulgaris inhibited the proliferation of human colon cancer cells (21). The carotenoid extract of $C$. ellipsoidea contains violaxanthin and two other xanthophylls, such as antheraxanthin and zeaxanthin, whereas the extract from $C$. vulgaris mainly contains lutein. The anti-cancer activity of carotenoid extracts was measured using the MTT assay after $24 \mathrm{~h}$ exposure to the two compounds. To confirm the apoptotic effects linked to the anti-proliferative effects, the authors also performed an annexin V-fluorescein assay and reported that the two extracts have an apoptotic effect (21). Fucoxanthin is a marine carotenoid that is mainly isolated from brown seaweeds and some microalgae $(22,23)$. Fucoxanthinol is the deacetylated derivative of fucoxanthin, and is an active form of fucoxanthin (24). One study has shown that fucoxanthin inhibits proliferation in colorectal cancer. The NMR analysis of fucoxanthin following degradation via ozonolysis showed that fucoxanthin divides into two types of cyclohexyl derivatives, and the treatment of degraded fucoxanthin induced antiproliferative effects in colon cancer (25). Another study has confirmed that fucoxanthin and fucoxanthinol have anticancer effects in colorectal cancer (26). The treatment with the two compounds induced an increase in dose dependent drug sensitivity, inhibited cancer cell growth, and induced apoptosis in colorectal cancer (26). Other study has indicated that fucoxanthinol reduaced cell viability of breast cancer cells via modulation of the NF-kappa B pathway. Fucoxanthin and fucoxanthinol decreased cell viability and induced apoptosis. Fucoxanthinol was more potent in inducing apoptosis compared to fucoxanthin (27). These results suggest that fucoxanthinol and fucoxanthin might be potential therapeutic reagents against different types of cancers, including colon and breast cancer.

Therapeutic effects on cancer of Polysaccharides from marine seaweed and algae. Polysaccharides, polymers of monosaccharides, are natural products that are present in a large amount in marine algae and are found intracellularly and in the cell wall. Some of them exert diverse pharmacological and anticancer effects: alginic acid fucoidan from brown algae and carrageenans from red algae $(28,29)$.

Carrageenans isolated from Kappaphycus alvarezii have been evaluated for their anticancer effects in vitro. The carrageenans suppressed the growth of breast, colon, liver, and osteosarcoma cell lines (30). In addition, carrageenan extracted from red seaweed of the Rhodophyceae family and L. papillosa showed cytotoxicity via inhibition of cell proliferation and induction of apoptosis in human intestinal cancer, breast cancer, and liver cancer cells $(31,32)$. Consistent with the anticancer activity, the administration of $\lambda$-carrageenan stimulated the immune system via up-regulation of proinflammatory IL17A and TNF- $\alpha$, thereby stimulating the activities of tumor infiltrating M1 macrophages, dendritic cells, and $\mathrm{T}$ lymphocytes (33). Furthermore, a recent study has confirmed that the extracted sulfated carrageenan (ESC) consists of l-carrageenan, which infers a direct damage to DNA by modulating nuclear condensation and DNA fragmentation in breast cancer MDA-MB-231 cells. ESC induced cell death via the apoptotic caspase 8 pathway (34).

The fucoidan isolated from the brown seaweeds Cladosiphon okamuranus and Fucus evanescens consists of fucose and galactose, mannose, and xylose (35). Fucoidan treatment suppressed cell proliferation, apoptosis, and migration via down-regulation of prion in colon cancers (36) and modulation of PI3K-AKT-GSK3b axis in breast cancer (37). In addition, administration of fucoidan for 28 days inhibited tumor growth and angiogenesis via modulation of JAK and STAT3 phosphorylation in animal studies (38). Furthermore, the administration of fucoidan suppressed endothelial mesenchymal transition (EMT) and induced apoptosis in breast cancer cells. Fucoidan inhibited cell migration and invasion via up-regulation of E-cadherin and down-regulation of MMP-9, and promoted apoptosis in breast cancer cells (39). In addition, fucoidan inhibited tumorigenesis and tumor growth via induction of ER stress, which resulted in apoptosis in vitro and in a lung cancer animal model. Fucoidan treatment increased the levels of reactive oxygen species (ROS), and induced an increase in ATF4, CHOP, and ER stress via modulation of Toll-like receptor 4 in lung cancer cells, leading to apoptosis and inhibition of cell proliferation (40).

Some studies confirmed successful applications of the complex of fucoidan and multiple nanoparticles in cancer therapy. One study employed the complex of fucoidan $(\mathrm{Fu})$ and synthetic rutin $(\mathrm{Ru})$ in anticancer therapy. Treatment with the Ru-Fu complex, which has no adverse effects on normal cells, resulted in disruption of cell cycle regulation and apoptosis via nuclear fragmentation, production of ROS, and induction of mitochondrial damage (41). Another study synthesized fucoidan-coated copper sulfide nanoparticles (F$\mathrm{CuS}$ ) as a candidate in chemo-photothermal cancer therapy. $\mathrm{F}-\mathrm{CuS}$, which acts as a nanocarrier promoting intracellular delivery of fucoidan, was applied as a photothermal agent in cancer cells. The administration of F-CuS induced cellular apoptosis following $808 \mathrm{~nm}$ diode laser irradiation in diverse cancer cells in vitro and in vivo (42). 
Anticancer activity of extracts of Ulva lactuca. Many studies indicated that a variety of Ulva lactuca extracts possess biological and pharmacological properties, including anticoagulant, antiviral, antioxidant, and anti-inflammatory properties (43-46). Extracts from the sea lettuce $U$. lactuca may have chemopreventive properties. Treatment of an DMBA-induced breast cancer rat model with ulvan polysaccharides for 10 weeks showed chemopreventive effects via prevention of histological alterations and carcinogenic lesions (47). Furthermore, ulvan polysaccharides have demonstrated cytotoxic effects against hepatocellular carcinoma (HCC), human breast cancer, and HeLa cells (48). In addition, administration of sulfated polysaccharides extracted from $U$. lactuca showed chemopreventive effects of DENA-induced hepatocarcinogenesis via suppression of cell proliferation and apoptosis induction. Treatment with these products improved hepatic damage and regulated antioxidant mechanisms, indicating their potential as novel chemopreventive and therapeutic agents for HCC (49).

These results indicate that diverse natural products derived from marine algae and seaweed show cytotoxic effects and could be novel agents for cancer therapy (Table I).

\section{The Anticancer Activity of Natural Products Isolated from Sea Cucumber}

Sea cucumbers belong to the class Holothuroidea, phylum Echinodermata, and are marine invertebrates that are phylogenetically associated with starfish, sea urchins, and sea lilies $(50,51)$. Sea cucumbers contain many nutrients and natural products, such as vitamins, calcium, triterpene glycosides, fucoidan, and sphingoid bases (51-55). Natural compounds extracted from sea cucumber have been reported to exhibit strong cytotoxic activity in human cancer cell lines (Table II).

The anticancer activity of Frondoside A and Cucumarioside A2-2. Frondoside A, isolated from Cucumaria frondosa exhibited enhanced apoptosis through increased expression of p53, p21 and caspase 3/7, 9 genes when used in the treatment of human breast and pancreatic cancer $(56,57)$. Frondoside A has been shown to enhance the therapeutic effects of the anti-cancer drugs oxaliplatin and 5-fluorouracil in colon cancer cells. Use of frondoside A enabled reduction in dosage of oxaliplatin or 5-fluorouracil. The combination treatment inhibited cell colony growth via inactivation of ERK 1/2 phosphorylation and induction of apoptosis (58). Another study has found that frondoside A extracted from sea cucumber Cucumaria okhotensis shows high anticancer activity in human prostate cancer, while normal cells were less affected. The mode of action included inhibition of cell proliferation and colony formation via induction of cell-cycle arrest and apoptosis and reduction of pro-survival autophagy in drug-resistant prostate cancer cells. Frondoside A has been shown to inhibit metastasis and bring about immunomodulatory effects by increasing in lymphocyte concentration (59). It also exhibited high cytotoxicity in urothelial carcinoma cells through induction of apoptosis by modulation of diverse apoptosisrelated proteins, such as caspase 3, 8, and 9, PARP, and through DNA fragmentation. It inhibited pro-survival autophagy and exhibited synergistic effects with cisplatin and gemcitabine (60). In addition, cucumarioside A2-2, isolated from the sea cucumber, Cucumaria japonica has been shown to exhibit cytotoxic effects in ehrlich carcinoma cells and to inhibit cell viability, cell proliferation, and DNA biosynthesis and to induce apoptosis via the caspase dependent pathway $(61,62)$.

The inhibitory effects of Echinoside A, Ds-echinoside A, Frondanol A5 on cancer cell proliferation. Echinoside A and Ds-echinoside A are triterpenoid glycosides, isolated from Pearsonothuria graeffei, and cause cell cycle arrest in hepatocellular carcinoma cells (63). Ds-echinoside A has been shown to inhibit the mouse double minute 2 homolog (MDM2) and C-X-C chemokine receptor type 4 (CXCR4), thereby enhancing apoptosis via modulation of p53, and to reduce cell proliferation and growth via protein tyrosine kinase 2 regulation (64). In addition, Ds-echinoside A has also been shown to inhibit proliferation of human hepatocellular carcinoma cells, and to suppress cell adhesion, migration, invasion, and angiogenesis via regulation of MMP9, TIMP-1, and VEGF expression (65). Frondanol A5 is an isopropyl alcohol/water extract derived from Cucumaria frondosa and its application has been shown to inhibit cell growth via modulation of p21WAF1/CIP and $\mathrm{Cdc} 25 \mathrm{c}$, thus inducing apoptosis of human colon cancer cells (66), as well as innate immune responses and inhibiting the growth of intestinal tumors in mice model (67). Frondanol A5P, a polar extract isolated from Cucumaria frondosa. has been shown to suppress cell proliferation and to induce cell cycle arrest via decrease in cell cycle-related proteins, such as cyclin A and cyclin B. It up-regulated stress-activated protein kinase, janus kinase, and p38 mitogen-activated protein kinase, resulting in enhanced apoptosis in pancreatic cancer cells (68).

The inhibitory effects of Philinopsides on cancer cell proliferation, migration, and angiogenesis. Philinopside A is isolated from the sea cucumber Pentacta quadrangularis and has been shown to inhibit cell proliferation, migration, and tube formation in human microvascular endothelial cells and animal models. Philinopside A also reduced tumor volume via induction of apoptosis and inhibited angiogenesis-related receptor tyrosine kinases, such as vascular endothelial growth factor (VEGF) receptor, fibroblast growth factor (FGF) receptor-1, platelet-derived growth factor (PDGF) 
Table I. The anticancer effects of marine seaweed-and algae-derived compounds.

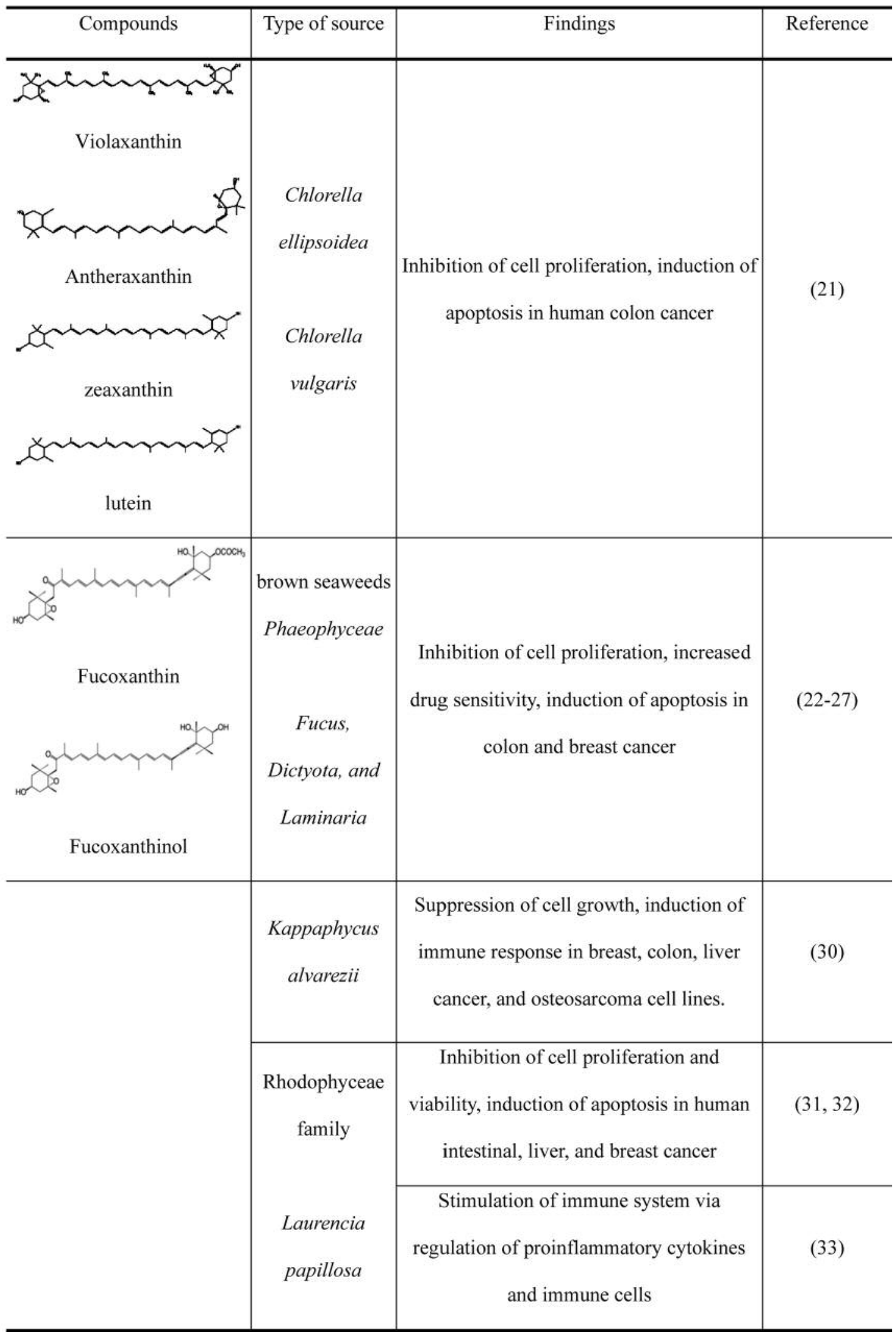

Table I. Continued 
Table I. Continued

\begin{tabular}{|c|c|c|c|}
\hline Compounds & Type of source & Findings & Reference \\
\hline lota carrageen & & $\begin{array}{l}\text { Induction of DNA damage via nuclear } \\
\text { condensation and DNA fragmentation, } \\
\text { enhancement of apoptosis in breast cancer }\end{array}$ & (34) \\
\hline \multirow{4}{*}{ Fucoidan } & \multirow{4}{*}{$\begin{array}{l}\text { Fucus } \\
\text { vesiculosus } \\
\text { Cladosiphon } \\
\text { okamuranus }\end{array}$} & $\begin{array}{l}\text { Inhibition of cell growth, reduction of cell } \\
\text { cycle related proteins by modulating of } \\
\text { prion expression in human colon cancer, } \\
\text { induction of apoptosis }\end{array}$ & (36) \\
\hline & & $\begin{array}{l}\text { Inhibition of cell proliferation, induction of } \\
\text { apoptosis via regulation of PI3K-AKT- } \\
\text { GSK3b in breast cancer }\end{array}$ & (37) \\
\hline & & $\begin{array}{l}\text { Inhibition of cell proliferation and } \\
\text { viability, cell migration and tube formation } \\
\text { in human prostate cancer, modulation of } \\
\text { JAK/STAT3 pathway, inhibition of tumor } \\
\text { growth, and angiogenesis in vivo }\end{array}$ & (38) \\
\hline & & $\begin{array}{l}\text { Suppression of EMT, induction of } \\
\text { apoptosis in breast cancer, inhibition of } \\
\text { migration and invasion via modulation of } \\
\text { E-cadherin and MMP9 }\end{array}$ & (39) \\
\hline
\end{tabular}

Table I. Continued 
Table I. Continued

\begin{tabular}{|c|c|c|c|}
\hline Compounds & Type of source & Findings & Reference \\
\hline & & $\begin{array}{l}\text { Inhibition of tumorigenesis and tumor } \\
\text { growth, induction of ROS production, ER } \\
\text { stress, and apoptosis in breast cancer }\end{array}$ & (40) \\
\hline & & $\begin{array}{l}\text { Complex of fucoidan and synthetic rutin, } \\
\text { disruption of cell cycle regulation, } \\
\text { induction of apoptosis via nuclear } \\
\text { fragmentation, production of ROS, and } \\
\text { increase of mitochondrial damage }\end{array}$ & (41) \\
\hline & & $\begin{array}{l}\text { Synthetic fucoidan-coated copper sulfide } \\
\text { nanoparticles, induction of the cellular } \\
\text { apoptosis }\end{array}$ & (42) \\
\hline$\sum_{\substack{\mathrm{OH} O \mathrm{OH} \\
\text { Rhamnose }}} \cdot \mathrm{H}_{2} \mathrm{O}$ & Ulva lactuca & $\begin{array}{l}\text { Prevention of histological alterations and } \\
\text { carcinogenic lesions in breast cancer rat } \\
\text { model, cytotoxic effects in hepatocellular } \\
\text { carcinoma, human breast cancer, and in } \\
\text { HeLa cells }\end{array}$ & $(47,48)$ \\
\hline
\end{tabular}

receptor-beta and epithelial growth factor (EGF) receptor (69). Philinopside E has been shown to interact with the extracellular domain of kinase domain containing receptor KDR and block the interaction between KDR and VEGF, thus inhibiting further downstream signalling pathway. These results indicated that philinopside $\mathrm{E}$ could inhibit cancer angiogenesis (70).

\section{The Potential Anticancer Activity of Starfish and Sea Urchin Extracted NPs}

The potential usage of NPS isolated from Starfish as anticancer reagent. Starfish contain diverse polar steroid, mono- and biglycosides of olyhydroxysteroids, as well as oligoglycosides. Starfish-derived steroid glycosides exert cytotoxic, neuritogenic, hemolytic, antiviral, antibacterial, antitumor, and cancer-preventive effects (71-73). One study has reported that two asterosaponins and six glycosylated polyhydroxylsteroids were isolated from the starfish Culcita novaeguineae. Among extracted products, four glycosylated polyhydroxylsteroids has shown slight cytotoxic effects against human hepatoma, epidermoid carcinoma, prostate cancer, breast cancer, and melanoma (74). Another study has confirmed the cytotoxic activity of six new polyhydroxylsteroidal glycosides and two previously known glycosides, which were isolated from starfish Anthenea sibogae. The mixture of two known glycosides has been shown to exert slightly inhibitory effects on cell proliferation in human breast cancer and to decrease colony size in vitro (75). Plancitoxin I derived from the venom of the crown-ofthorns starfish Acanthaster planci, has been reported to exert strong cytotoxic effects in human malignant melanoma cells $(76,77)$. Plancitoxin I decreased cell viability via induction of ROS, nitric oxide production, and reduction of mitochondrial 
Table II. Mode of action of anticancer activity of compounds extracted from marine sea cucumber.

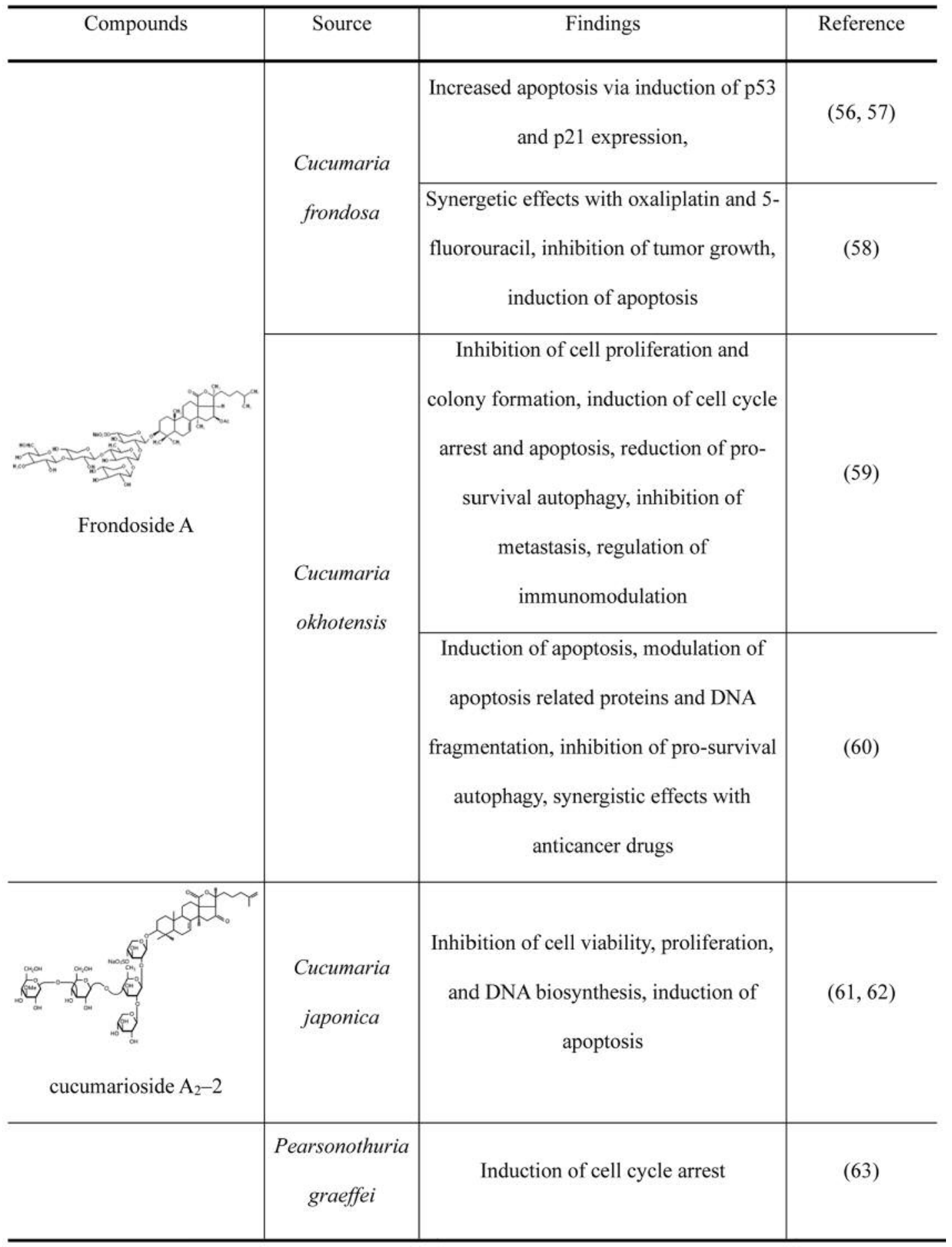

Table II. Continued

membrane potential, inducing apoptosis (77). Another study has confirmed that pancitoxin I reduced antioxidant enzymes such as SOD and catalase, and induced mitochondrial dysfunction. Moreover, pancitoxin I increased $\mathrm{Ca}^{(2+)}$ concentrations and induced ER stress, subsequently elevating apoptosis via an increase in apoptosis related proteins such as caspase 3, 8, and 9 (76). In addition, cyclic steroid glycosides isolated from starfish Echinaster luzonicus, such as 
Table II. Continued

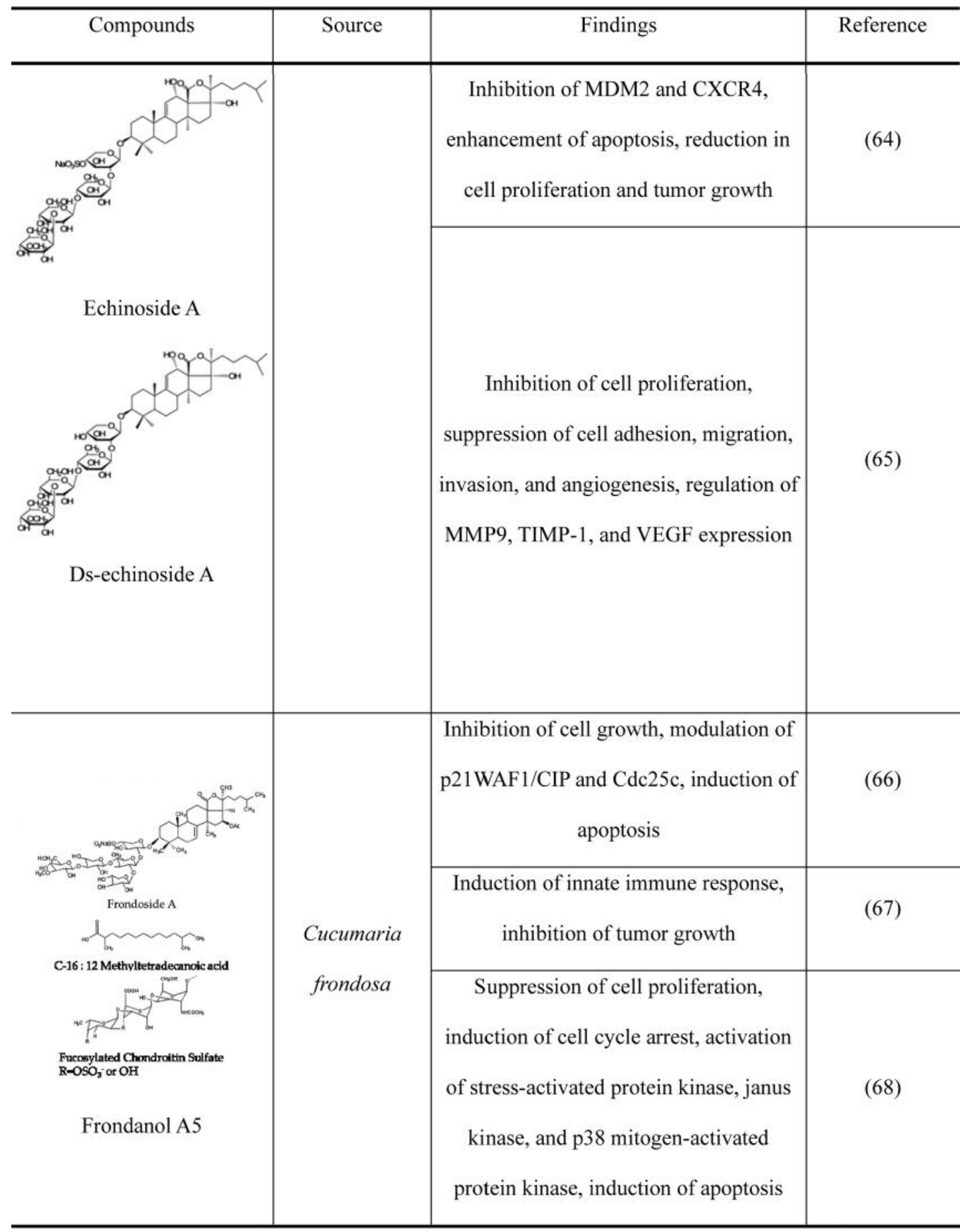

Table II. Continued

luzonicoside A and D, have been shown to have anticancer activity in human melanoma. Luzonicoside A and D inhibited cell proliferation, colony formation, and migration via regulation of cell cycle and apoptosis induction (78).
The potential anticancer activity of NPs extracted from sea urchin. Sea urchins belong to echinoderms and are part of the same group of invertebrates, such as starfish, brittle stars, and sponges (79). Extracts derived from sea urchins have 
Table II. Continued

\begin{tabular}{l|r|r|r}
\hline Compounds & Source & Findings & Reference \\
\hline Inhibition of cell proliferation, & Pentacta & migration, and tube formation, reduction & \\
of tumor growth, induction of apoptosis, & (69) \\
\hline
\end{tabular}

been shown to exhibit diverse biological properties such as anti-tumor activity and immunomodulation. The steroidal components from sea urchin Diadema savignyi Michelin were isolated and their cytotoxic activity was confirmed in human cancer cell lines, including human promyelocytic leukemia, prostate cancer, and embryonic lung cells. The steroidal components inhibited cell proliferation and viability and induced apoptosis via modulation of apoptosis-related protein expression, inactivation of MAPK pathway, and decrease in c-Myc expression (80). Ovothiols, extracted from eggs of the sea urchin Paracentrotus lividus, have been shown to play an important role in the protection of cells via modulation of the cellular redox balance and recycling of oxidized glutathione. In addition, one study has suggested that ovothiols may decrease cell proliferation via activation of autophagy in human liver carcinoma cells, without affecting normal lung cells (81). In another study, treatment with strongylocentrotus nudus egg polysaccharide (SEP), isolated from the eggs of sea urchins, was found to exhibit immunomodulatory activity via enhancement of splenocyte proliferation and stimulation of $\mathrm{B}$ and $\mathrm{T}$ cell proliferation. However, SEP treatment did not directly affect cancer cells, and the anticancer effects of SEP were associated with modulation of immune system functions (82). During investigation of the anti-cancer activity of four glycolipids extracted from the intestine of the sea urchin Strongylocentrotus intermedius, only one glycolipid (sulphonoquinovosyl-lysoglyceride) was found to exhibit significant cytotoxic effect in human lung adenocarcinoma. The application of the extract inhibited tumor growth and induced necrosis in mouse model (83). These results indicate that starfish and sea urchin derived extracts need to be further studied to establish their anticancer activity against different types of cancer (Table III).

\section{The Therapeutic Effects of NPs Derived from Marine Sponges and Tunicate and Clinical Trials of Cancer Therapy}

Marine sponges belong to the phylum Porifera and are the richest source of natural marine compounds (84). Diverse molecules derived from marine sponges, such as nucleosides, sterols, alkaloids, and amino acid derivatives have been discovered and at least 60 of them have be shown to have potential chemopreventive and anticancer activities $(85,86)$. These properties of marine sponge-derived natural products are affected by multiple cellular and molecular processes, such as cell cycle, apoptosis, and inflammation (Table IV). 
Table III. Mode of action of anticancer activity of marine starfish and sea urchin derived compounds.

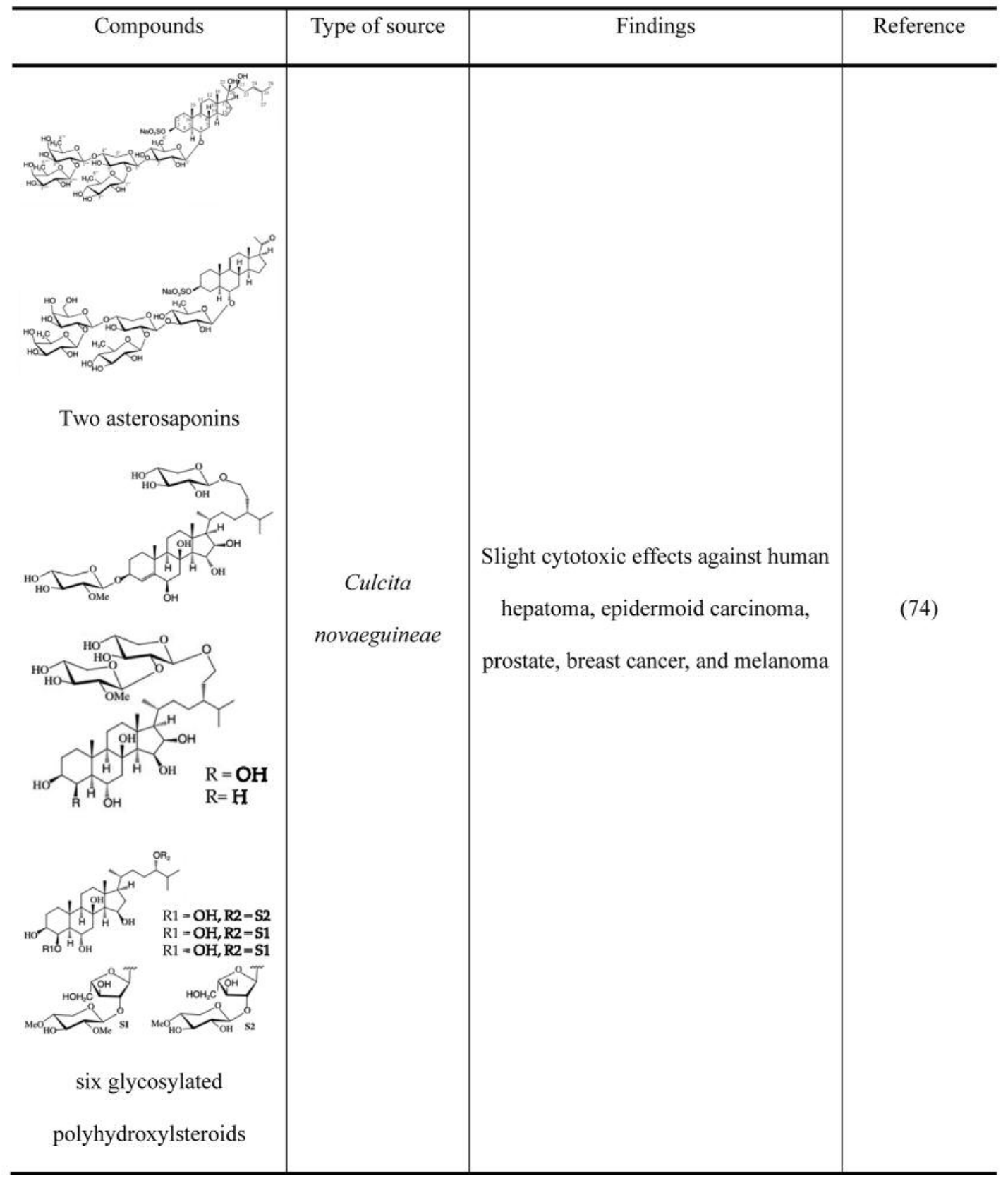

Table III. Continued

The preclinical and clinical trials of cancer therapy using Renieramycin $M$ and its derivatives. Renieramycin M (RM) isolated from the blue sponge Xestospongia sp. is a tetrahydroisoquinoline, and is the first marine anticancer drug approved by the European Union and the Food and Drug Administration (FDA) for the treatment of advanced soft tissue sarcomas (87). These products have shown cytotoxic activity in human colon, lung, prostate, brain, and breast cancer cells (88-90). Treatment with RM isolated from the sponge Xestospongia species showed cytotoxic effects against lung cancer stem cells (CSC), reduced colony and spheroid formation, as well as CSC markers, such as CD133, CD44, and ALDH1A (90). Moreover, RM treatment has shown a therapeutic effect by resensitizing anoikis in anoikis-resistant lung cancer cells. Anoikis resistance is 
Table III. Continued

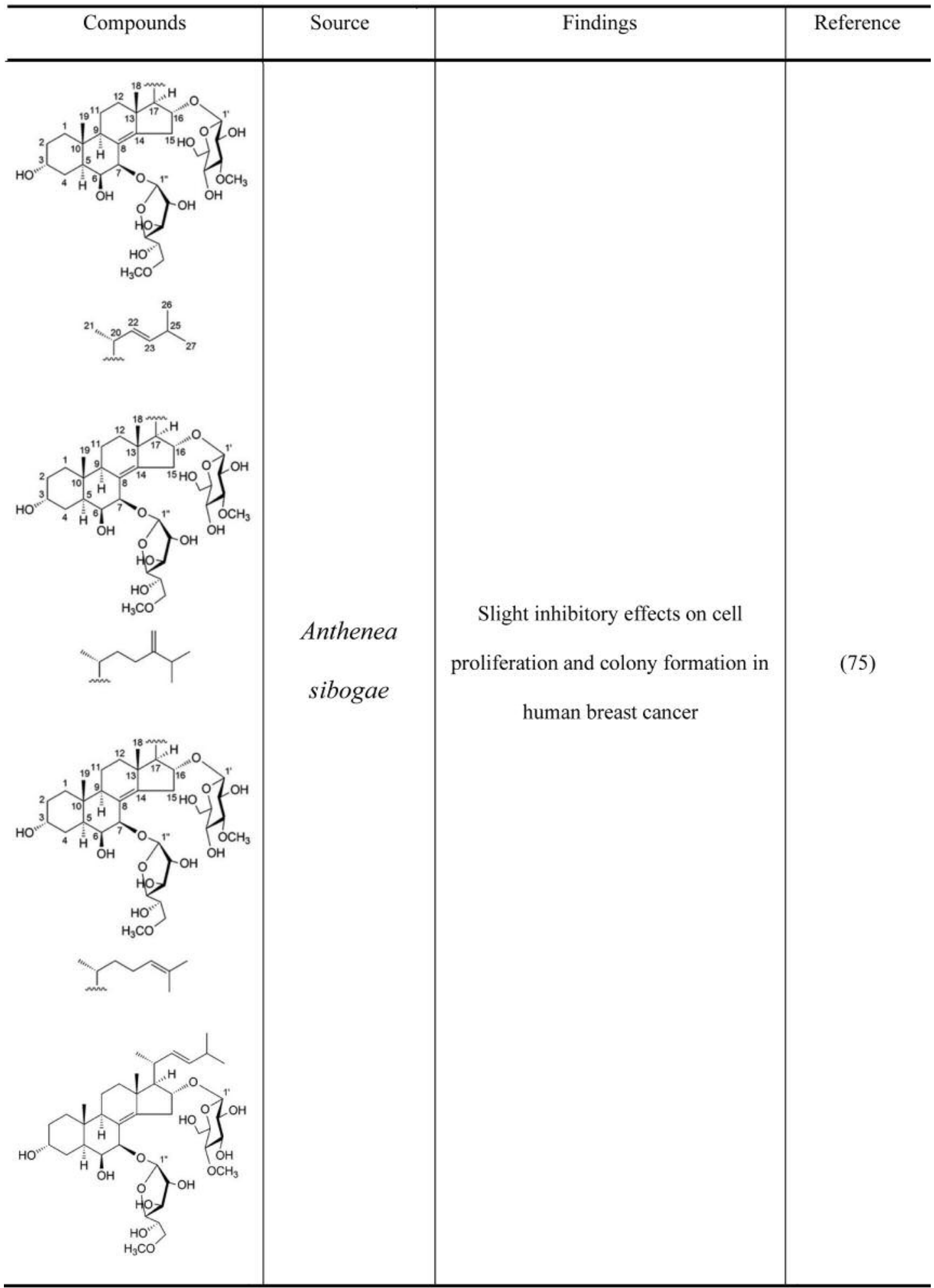

Table III. Continued 
Table III. Continued

\begin{tabular}{|c|c|c|c|}
\hline Compounds & Source & Findings & Reference \\
\hline (c) & & & \\
\hline \multirow[t]{2}{*}{$\begin{array}{c}\text { Plancitoxin I } \\
\text { (GenBank: BAD13432) }\end{array}$} & \multirow[t]{2}{*}{$\begin{array}{c}\text { Acanthaster } \\
\text { planci }\end{array}$} & $\begin{array}{l}\text { Decrease in cell viability, induction of } \\
\text { ROS and nitric oxide production, } \\
\text { reduction of mitochondrial membrane } \\
\text { potential, induction of apoptosis }\end{array}$ & (77) \\
\hline & & $\begin{array}{l}\text { Reduction in antioxidant enzymes, } \\
\text { induction of mitochondrial } \\
\text { dysfunction, ER stress, and apoptosis }\end{array}$ & (76) \\
\hline
\end{tabular}


Table III. Continued

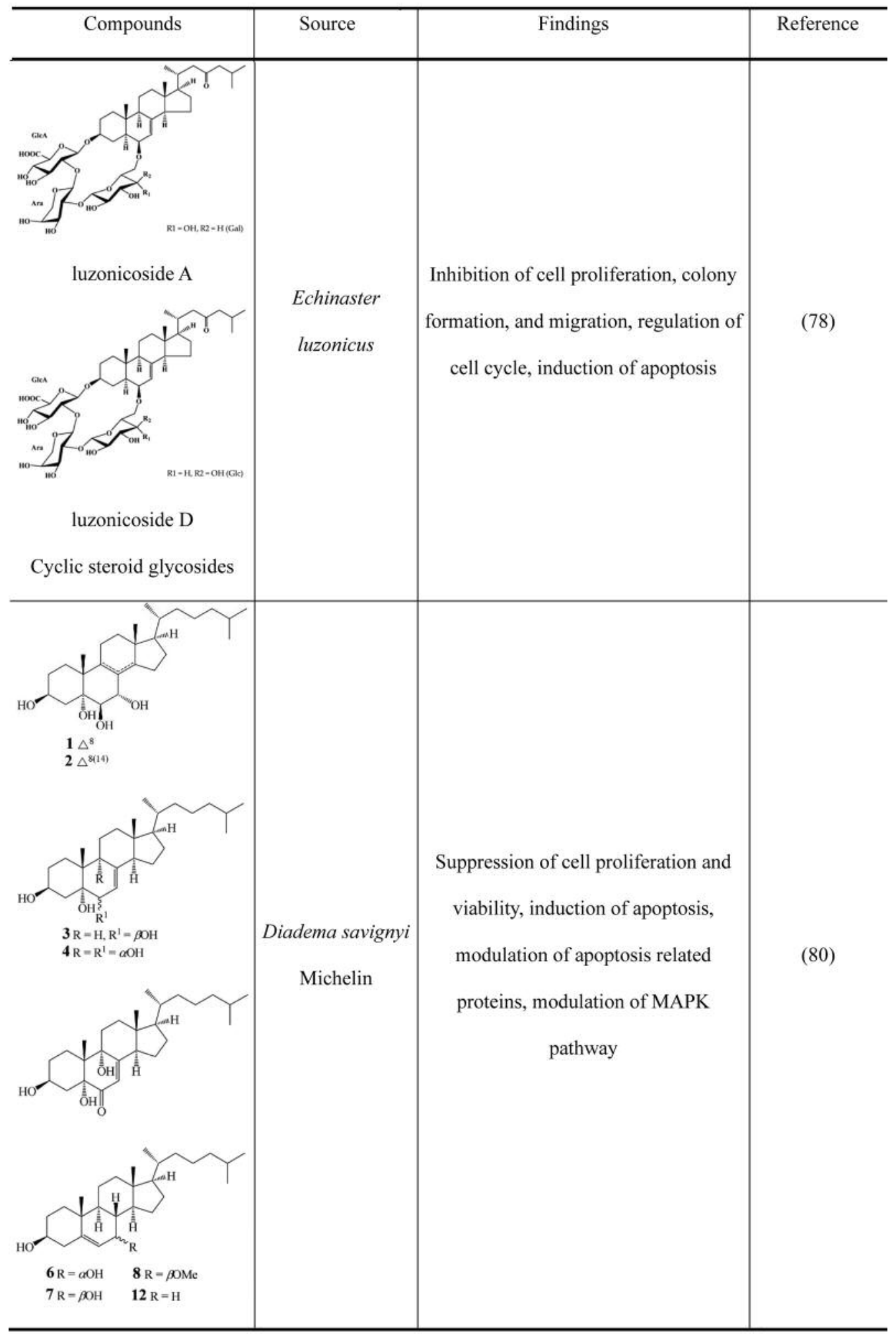

Table III. Continued 
Table III. Continued

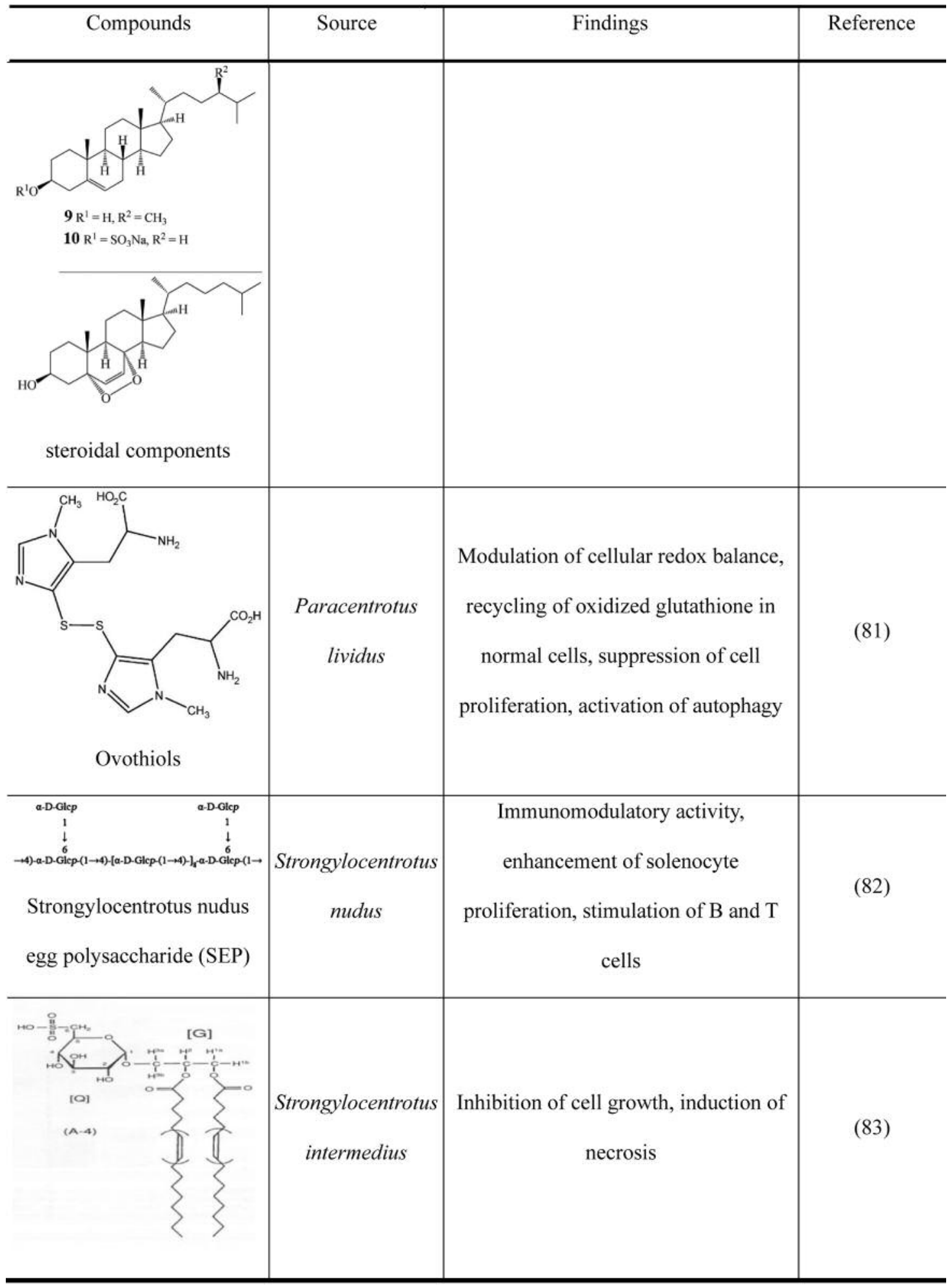




\begin{tabular}{l|l|l|l}
\hline Compounds & Source & Findings & Reference \\
\hline sulphonoquinovosyl- & & & \\
\hline \\
lysoglyceride & & & \\
\hline
\end{tabular}

induced by modulating the up-regulation of survival and anti-apoptotic proteins, such as phosphorylated extracellular signal-regulated kinase (p-ERK), phosphorylated ATPdependent tyrosine kinase (p-AKT), and B-cell lymphoma-2 (BCL2). RM significantly suppressed cell viability and the expression of p-ERK, p-AKT, and BCL2 (91). Further, hydroquinone 5-O-cinnamoyl ester (CIN-RM), a newlysynthesized derivative of RM, has been shown to be more cytotoxic against non-small cell lung cancer cells compared to RM. CIN-RM treatment induced apoptosis by increasing apoptosis inducing factor and by activating of caspase 3 and 9 through a p53-dependent mechanism (92). Another study has reported the formation of bishydroquinone renieramycin M (HQ-RM) by modifying the quinone ring of RM. HQ-RM treatment has been shown to have stronger cytotoxic effects compared to RM. HQ-RM reduced the viability of lung cancer cells and induced apoptosis by increasing proapoptotic proteins, such as BAX, and decreasing the antiapoptotic proteins BCL2 and MCL via mitochondrial apoptosis (93).

The clinical trials and therapeutic effects of Cytarabine and Zalypsis. Werner Bergmann's group isolated arabino nucleoside spongothymidine and spongouridine from the Caribbean sponge Cryptotethya crypta (94). Cytarabine (AraC) is the synthetic analog of natural arabino nucleosides and cytosine arabinose and has been used as an anti-metabolite drug in cancer therapy. An anti-metabolite drug is similar to the structure of a natural metabolite and blocks normal cell metabolism (95). Cytarabine has been shown to interrupt DNA synthesis $(96,97)$ and approved for clinical use in
1969 and is still widely used in the treatment of various types of leukemia. Cytarabine is commonly used for the treatment of acute leukemia therapy. Treatment with cytarabine has been shown to induce apoptosis via phosphatidylserine exposure, caspase activation, and inhibition of RNA synthesis in B-chronic lymphocytic leukemia (98). In acute myeloid leukemia therapy, cytarabine is also used as one of the important drugs. Treatment with cytarabine has been shown to inhibit cell growth and to induce apoptosis via regulation of autophagy pathway in human leukemia cell lines (99).

Zalypsis ${ }^{\circledR}$ is a newly synthetic dimeric isoquinoline alkaloid structurally related to renieramycin $\mathrm{J}$ isolated from the species of marine sponge, Netropsia. The molecular pharmacology of this compoud has been reported to be similar to that of ET743, but it does not activate the DNA damage checkpoint response (100). Treatment of Zalypsis ${ }^{\circledR}$ has been shown to increase double strand breaks (DSBs), inhibit transcription and cell cycle, and then increase apoptosis in human cancer cells (100). In addition, Zalypsis ${ }^{\circledR}$ has shown potent anti-leukemic activity and synergetic effect with conventional antileukemic drugs, including cytarabine, fludarabine and daunorubicin. Treatment of Zalypsis ${ }^{\circledR}$ has been shown to induce apoptosis via modulation of DSBs related pathway in leukemia cells and patients samples (101). Zalypsis ${ }^{\circledR}$ has been tested three Phase I/II clinical trials. One clinical trial, aimed at developing novel treatments for advanced malignant solid tumors or lymphoma, was terminated (NCT00359294). This Phase I study investigated the safety, tolerability, dose limiting toxicity and recommended dose of Zalypsis ${ }^{\circledR}$. Another clinical trial, 
Table IV. The anticancer effects of compounds extracted from marine sponges.

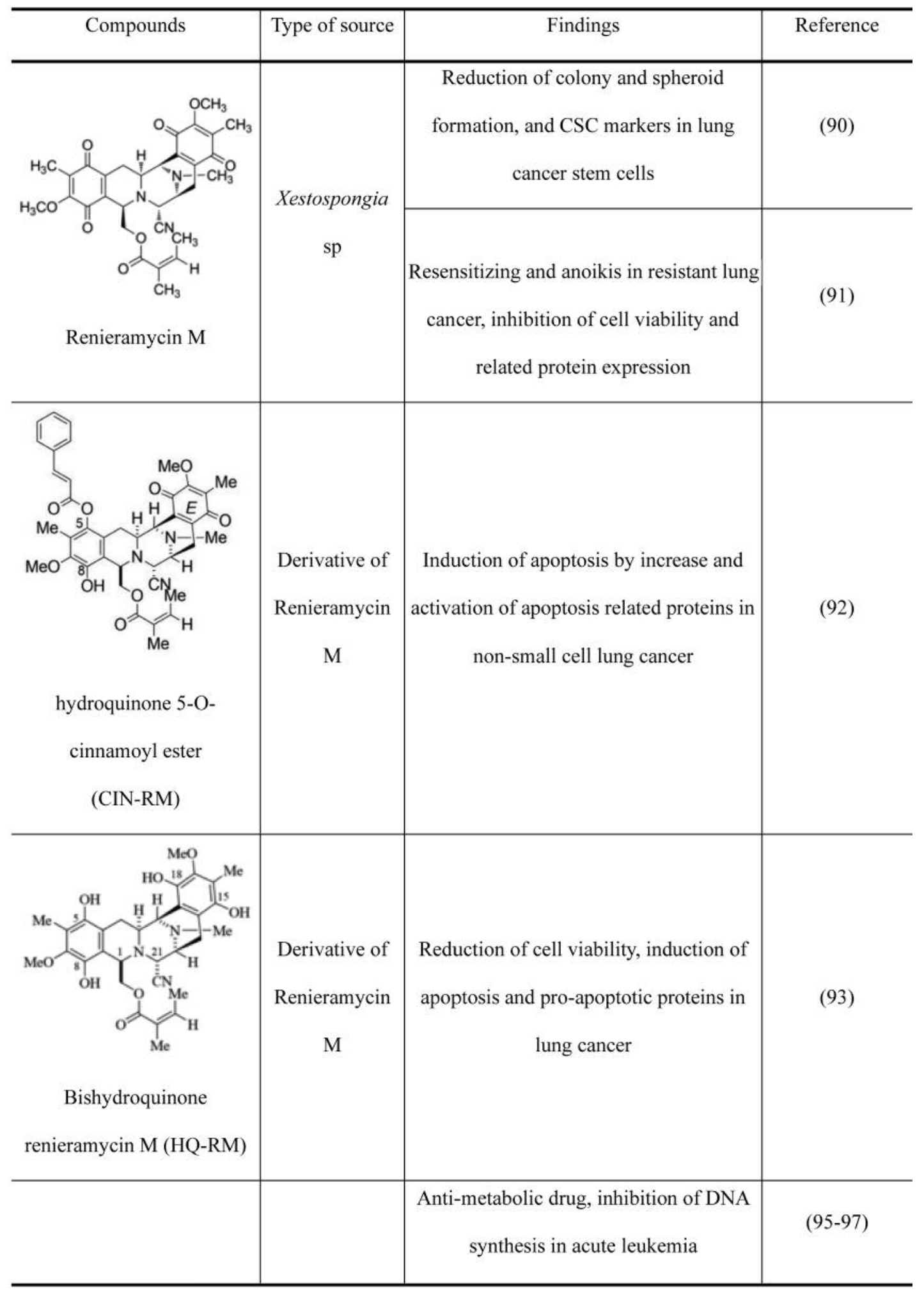


Table VI. Continued

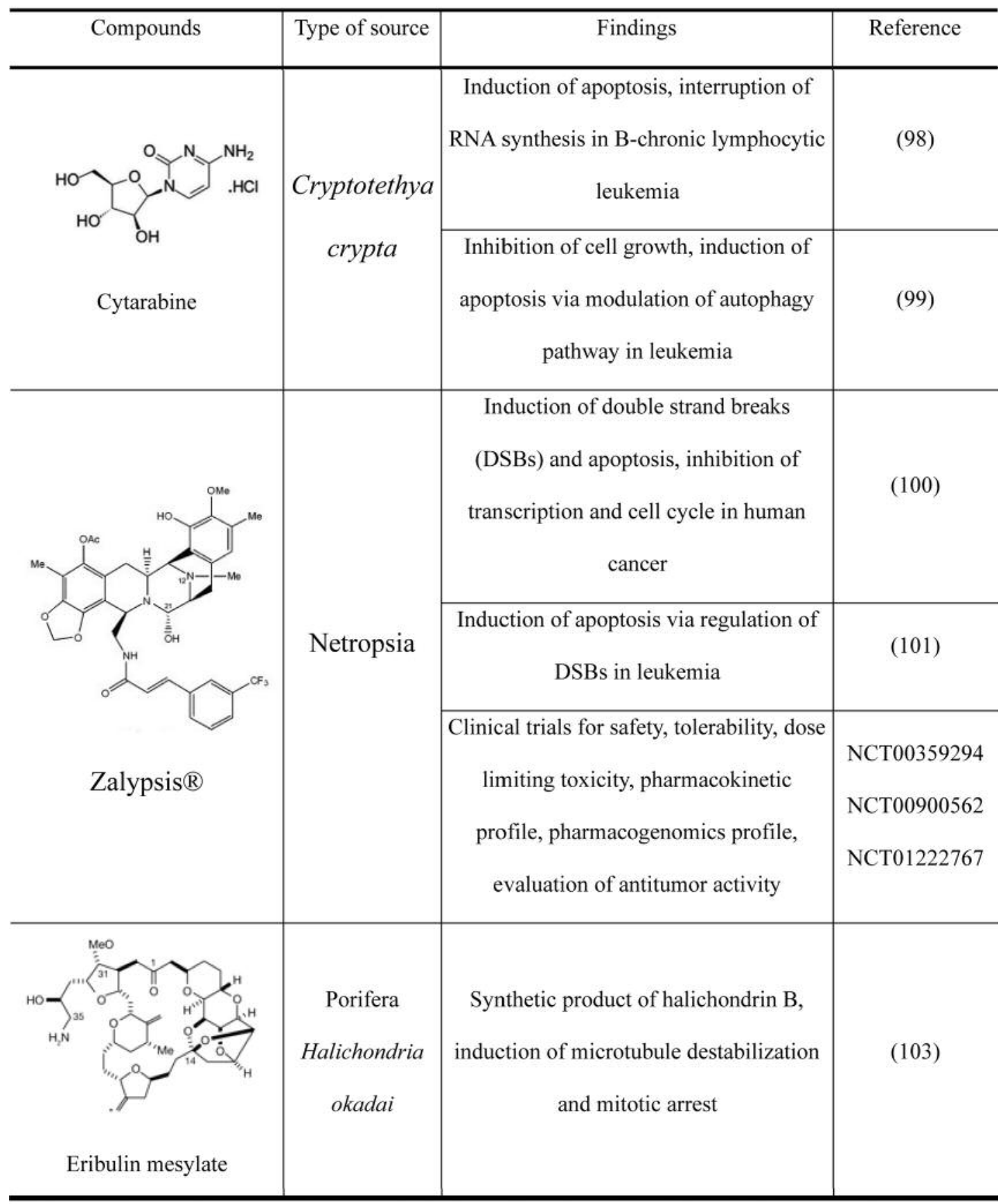

aimed at developing novel treatments for advanced and/or metastatic endometrial or cervical cancer, was also terminated (NCT00900562). This Phase II study evaluated the antitumor activity, safety profile, pharmacokinetic profile and pharmacogenomic profile of Zalypsis ${ }^{\circledR}$. The third clinical trial, aimed at developing novel treatments for unresectable locally advanced and/or metastatic Ewing family of tumors, has been completed (NCT01222767). This Phase II study evaluated the antitumor activity of Zalypsis ${ }^{\circledR}$.

The clinical trials and therpeutic effects Eribulin mesylate and E7974 on cancer. Eribulin mesylate is a synthetic 
Table VI. Continued

\begin{tabular}{l|c|c|c}
\hline Compounds & Type of source & Findings & Reference \\
\hline minor & $\begin{array}{c}\text { Synthetic product of hemiasterlin, } \\
\text { suppression of microtubule } \\
\text { polymerization binding, induction of cell } \\
\text { cycle arrest and apoptosis }\end{array}$ & $\begin{array}{l}\text { NCT09,111) } \\
\text { NCT00165802, }\end{array}$ \\
\hline
\end{tabular}

product of halichondrin B isolated from the Poriferan Halichondria okadai, and it is the only commercial anticancer drug derived from marine sponges available for the treatment of breast cancer (102). Eribulin mesylate has been shown to induce microtubule destabilization, which leads to irreversible mitotic arrest via the formation of abnormal mitotic spindles (103). In addition, eribulin mesylate has been shown to reverse the epithelial-tomesenchymal transition in cancer (104). Eribulin mesylate has shown anticancer activity against diverse cancers, including breast, ovarian, colon, and pancreatic cancer (105107). In a clinical study, administration of eribulin mesylate has shown anticancer effects with manageable side effects including neutropenia and fatigue (108). E7974 is a synthetic product of hemiasterlin, which is extracted from the marine sponge Hemiasterella minor $(109,110)$. E7974 has been found to suppress microtubule polymerization and to alter the mitotic spindle, thus inducing cell cycle arrest and apoptosis. E7974 has shown an inhibitory effect on cell proliferation in several cancer cell lines (111). Three Phase I clinical trials with E7974 have been completed (NCT00165802, NCT00130169, NCT00121732). These clinical trials have been performed in patients with refractory solid tumors and therapeutic effects of E7974 were observed. Administration of E7974 has shown reversible and manageable side-effects.
The clinical trials and therapeutic effects of NPs isolated from Tunicate as anticancer agents. Trabectedin is a synthetic marine-derived alkylating agent extracted from the Caribbean tunicate, Ecteinascidia turbinata (112). Trabectedin has succeeded in the treatment of soft tissue sarcomas in preliminary clinical trials and approved in the EU for treatment of advanced soft tissue sarcoma and recurrent platinum-sensitive ovarian cancer. Currently, large, randomized phase III clinical trials proceed in many countries. One clinical trial, aimed at developing combination therapy of gemcitabine and trabectedin for Lsarcomas, has been completed (NCT01426633) (113). This Phase I study evaluated the antitumor activity of combination therapy and provided negative results for the treatment of advanced and/or metastatic leiomyosarcoma or liposarcoma. Another clinical trial, aimed at developing combination therapy with doxorubicin and trabectedin for soft tissue sarcoma, has also been completed (NCT00102609) (114). This Phase I study evaluated the safety and toleration, and antitumor activity of the combination therapy, and the results showed that the combination therapy is safe and well tolerated, and exerts anticancer activity. A phase II clinical trial, aimed at confirming the therapeutic effect of trabectedin for retroperitoneal leiomyosarcoma and well differentiated/dedifferentiated liposarcoma, has also been completed (NCT02247544). This Phase II study assessed the 


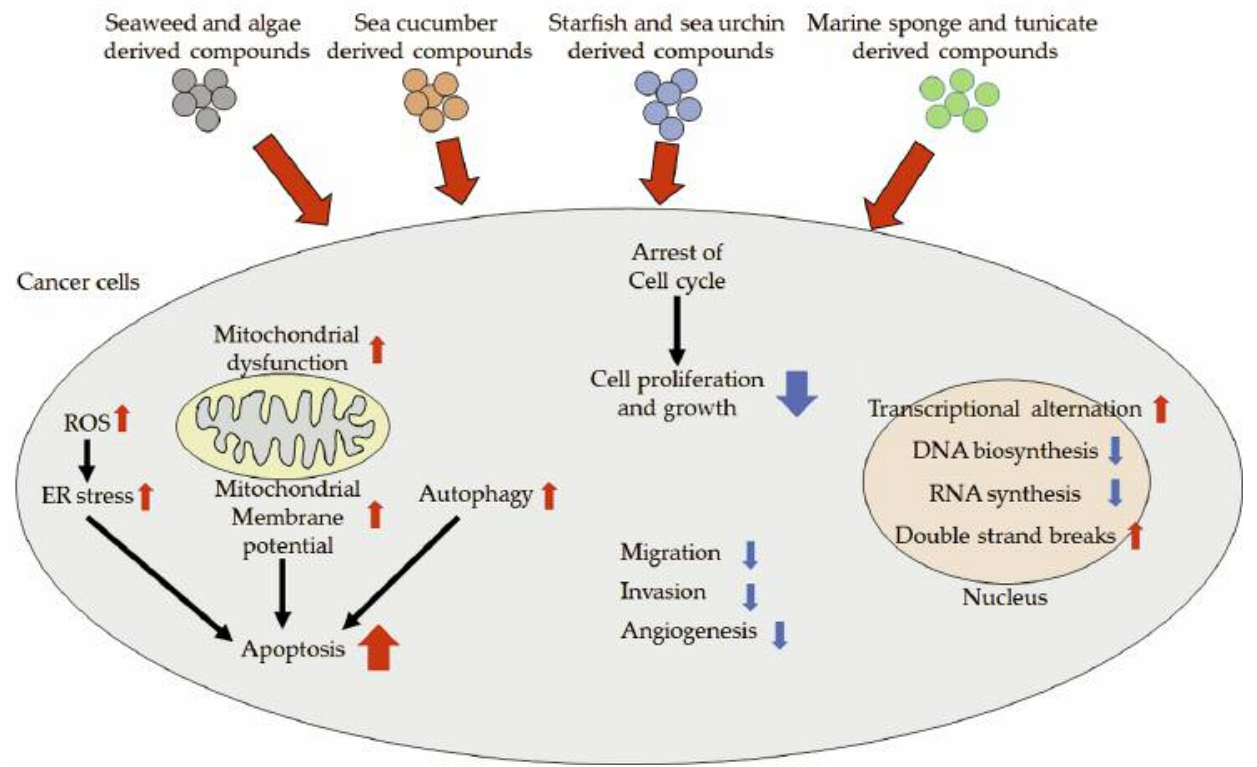

Figure 1. A schema illustrating the overview of anticancer activity of marine-derived compounds in diverse cancers.

activity of trabectedin as a secondary treatment. This clinical study is completed, but the results are not yet published. A phase III trial clinical, aimed at confirming the therapeutic efficacy and safety of trabectedin for advanced relapsed ovarian cancer, has also been completed (NCT00113607) (115). This Phase III study assessed the effect of conbination of trabectedin and pegylated liposomal doxorubicin. The results showed that the combination treatment has little or no decrement in patient-reported functional status and symptoms, and led to manageable and non-cumulative toxicity with fewer adverse events and a significant improvement in progression-free survival and overall response rate.

\section{Conclusion}

Marine organisms have provided a promising source of useful natural products, molecules, and drugs for therapeutic use. The results of numerous studies, summarized in this review, suggest that natural products derived from marine organisms are novel candidate therapeutic agents for the prevention and treatment of cancer. Marine extracts possess cytotoxic activity against many cancers, including breast and colon cancer, via inhibition of cell proliferation and cell viability, induction of ROS production, mitochondrial dysfunction, ER stress, and apoptosis. In addition, many marine organisms are promising sources of anticancer compounds and have shown beneficial effects upon combination with traditional anticancer drugs (Figure 1). However, it is still necessary to further study the natural products isolated from a large number of marine species.

The therapeutic and commercial usage of promising marine natural product is dependent on the results of preclinical and clinical studies. Many studies have reported that marine isolated natural products and its derivatives show potential therapeutic efficacy for cancer therapy. Cytarabine and Zalypsis have been studied in many preclinical and clinical trials and are used to treat various leukemias and cancer. Also, eribulin mesylate and E7974 have proceeded to clinical trials to investigate their therapeutic effects on several cancers. Currently, many marine derived compounds have been reported to be in the process of development into drugs. Therefore, it is necessary to study the anticancer activities of marine extracted natural products in order to develop novel anticancer drugs for diverse cancers.

\section{Conflicts of Interest}

The Authors have no conflicts of interest to declare with regards to this study.

\section{Authors' Contributions}

Chul Won Yun: Data collection and drafting of manuscript; Hyung Joo Kim: drafting of manuscript; Sang Hun Lee: organizing the structure of the manuscript, drafting and editing of the manuscript, procurement of funding. 


\section{Acknowledgements}

This work was supported by a National Research Foundation grant funded by the Korean government (Grant number: NRF2016R1D1A3B01007727 and NRF-2017M3A9B4032528).

\section{References}

1 Torre LA, Bray F, Siegel RL, Ferlay J, Lortet-Tieulent J and Jemal A: Global cancer statistics, 2012. CA Cancer J Clin 65(2): 87-108, 2015. PMID: 25651787. DOI: $10.3322 /$ caac. 21262

2 Macdonald S, Cunningham Y, Patterson C, Robb K, Macleod U, Anker $\mathrm{T}$ and Hilton S: Mass media and risk factors for cancer: The under-representation of age. BMC Public Health 18(1): 490, 2018. PMID: 29695238. DOI: 10.1186/s12889-018-5341-9

3 Kumar MS and Adki KM: Marine natural products for multitargeted cancer treatment: A future insight. Biomed Pharmacother 105: 233-245, 2018. PMID: 29859466. DOI: 10.1016/j.biopha.2018.05.142

4 Vogelstein B and Kinzler KW: Cancer genes and the pathways they control. Nat Med 10(8): 789-799, 2004. PMID: 15286780. DOI: $10.1038 / \mathrm{nm} 1087$

5 Miller KD, Siegel RL, Lin CC, Mariotto AB, Kramer JL, Rowland JH, Stein KD, Alteri R and Jemal A: Cancer treatment and survivorship statistics, 2016. CA Cancer J Clin 66(4): 271289, 2016. PMID: 27253694. DOI: 10.3322/caac.21349

6 Oliphant R, Nicholson GA, Horgan PG, Molloy RG, McMillan DC, Morrison DS and West of Scotland Colorectal Cancer Managed Clinical N: Deprivation and colorectal cancer surgery: Longer-term survival inequalities are due to differential postoperative mortality between socioeconomic groups. Ann Surg Oncol 20(7): 2132-2139, 2013. PMID: 23529783. DOI: 10.1245/s10434-013-2959-9

7 Amin AR, Kucuk O, Khuri FR and Shin DM: Perspectives for cancer prevention with natural compounds. J Clin Oncol 27(16): 2712-2725, 2009. PMID: 19414669. DOI: 10.1200/ JCO.2008.20.6235

8 Newman DJ, Cragg GM and Snader KM: Natural products as sources of new drugs over the period 1981-2002. J Nat Prod 66(7): 1022-1037, 2003. PMID: 12880330. DOI: 10.1021/ np0300961

9 Shu YZ: Recent natural products based drug development: A pharmaceutical industry perspective. J Nat Prod 61(8): 10531071, 1998. PMID: 9722499. DOI: $10.1021 / n p 9800102$

10 Pinto D and Silva AMS: Anticancer natural coumarins as lead compounds for the discovery of new drugs. Curr Top Med Chem 17(29): 3190-3198, 2017. PMID: 29243581. DOI: $10.2174 / 1568026618666171215095750$

11 Haefner B: Drugs from the deep: Marine natural products as drug candidates. Drug Discov Today 8(12): 536-544, 2003. PMID: 12821301.

12 Simmons TL, Andrianasolo E, McPhail K, Flatt P and Gerwick WH: Marine natural products as anticancer drugs. Mol Cancer Ther 4(2): 333-342, 2005. PMID: 15713904.

13 Sagar S, Kaur M and Minneman KP: Antiviral lead compounds from marine sponges. Mar Drugs 8(10): 2619-2638, 2010. PMID: 21116410. DOI: $10.3390 / \mathrm{md} 8102619$

14 Snelgrove PV: An ocean of discovery: Biodiversity beyond the census of marine life. Planta Med 82(9-10): 790-799, 2016. PMID: 27093252. DOI: $10.1055 / \mathrm{s}-0042-103934$
15 Blunt JW, Copp BR, Keyzers RA, Munro MHG and Prinsep MR: Marine natural products. Nat Prod Rep 34(3): 235-294, 2017. PMID: 28290569. DOI: 10.1039/c6np00124f

16 Pye CR, Bertin MJ, Lokey RS, Gerwick WH and Linington RG: Retrospective analysis of natural products provides insights for future discovery trends. Proc Natl Acad Sci USA 114(22): 5601-5606, 2017. PMID: 28461474. DOI: 10.1073/pnas.16146 80114

17 Bocanegra A, Bastida S, Benedi J, Rodenas S and SanchezMuniz FJ: Characteristics and nutritional and cardiovascularhealth properties of seaweeds. J Med Food 12(2): 236-258, 2009. PMID: 19459725. DOI: 10.1089/jmf.2008.0151

18 Jaswir I, Monsur HA, Simsek S, Amid A, Alam Z, bin Salleh MN, Tawakalit AH and Octavianti F: Cytotoxicity and inhibition of nitric oxide in lipopolysaccharide induced mammalian cell lines by aqueous extracts of brown seaweed. J Oleo Sci 63(8): 787-794, 2014. PMID: 25007746.

19 Romano G, Costantini M, Sansone C, Lauritano C, Ruocco N and Ianora A: Marine microorganisms as a promising and sustainable source of bioactive molecules. Mar Environ Res 128: 58-69, 2017. PMID: 27160988. DOI: 10.1016/j.marenvres.2016.05.002

20 de Morais MG, Vaz Bda S, de Morais EG and Costa JA: Biologically active metabolites synthesized by microalgae. Biomed Res Int 2015: 835761, 2015. PMID: 26339647. DOI: $10.1155 / 2015 / 835761$

21 Cha KH, Koo SY and Lee DU: Antiproliferative effects of carotenoids extracted from chlorella ellipsoidea and chlorella vulgaris on human colon cancer cells. J Agric Food Chem 56(22): 10521-10526, 2008. PMID: 18942838. DOI: 10.1021/jf802111x

22 Satomi Y: Antitumor and cancer-preventative function of fucoxanthin: A marine carotenoid. Anticancer Res 37(4): 15571562, 2017. PMID: 28373414. DOI: 10.21873/anticanres.11484

23 Peng J, Yuan JP, Wu CF and Wang JH: Fucoxanthin, a marine carotenoid present in brown seaweeds and diatoms: Metabolism and bioactivities relevant to human health. Mar Drugs 9(10): 1806-1828, 2011. PMID: 22072997. DOI: 10.3390/md9101806

24 Hashimoto T, Ozaki Y, Mizuno M, Yoshida M, Nishitani Y, Azuma $\mathrm{T}$, Komoto A, Maoka $\mathrm{T}$, Tanino $\mathrm{Y}$ and Kanazawa $\mathrm{K}$ : Pharmacokinetics of fucoxanthinol in human plasma after the oral administration of kombu extract. Br J Nutr 107(11): 1566-1569, 2012. PMID: 21920061. DOI: 10.1017/S0007114511004879

25 Komba S, Kotake-Nara E and Tsuzuki W: Degradation of fucoxanthin to elucidate the relationship between the fucoxanthin molecular structure and its antiproliferative effect on caco-2 cells. Mar Drugs 16(8), 2018. PMID: 30082622. DOI: $10.3390 / \mathrm{md} 16080275$

26 Takahashi K, Hosokawa M, Kasajima H, Hatanaka K, Kudo K, Shimoyama $\mathrm{N}$ and Miyashita K: Anticancer effects of fucoxanthin and fucoxanthinol on colorectal cancer cell lines and colorectal cancer tissues. Oncol Lett 10(3): 1463-1467, 2015. PMID: 26622691. DOI: 10.3892/ol.2015.3380

27 Rwigemera A, Mamelona J and Martin LJ: Inhibitory effects of fucoxanthinol on the viability of human breast cancer cell lines mcf-7 and mda-mb-231 are correlated with modulation of the nf-kappab pathway. Cell Biol Toxicol 30(3): 157-167, 2014. PMID: 24760606. DOI: 10.1007/s10565-014-9277-2

28 Gutierrez-Rodriguez AG, Juarez-Portilla C, Olivares-Banuelos $\mathrm{T}$ and Zepeda RC: Anticancer activity of seaweeds. Drug Discov Today 23(2): 434-447, 2018. PMID: 29107095. DOI: $10.1016 / j$.drudis .2017 .10 .019 
29 Senthilkumar K, Manivasagan P, Venkatesan J and Kim SK: Brown seaweed fucoidan: Biological activity and apoptosis, growth signaling mechanism in cancer. Int J Biol Macromol 60: 366-374, 2013. PMID: 23817097. DOI: 10.1016/j.ijbiomac.2013.06.030

30 Suganya AM, Sanjivkumar M, Chandran MN, Palavesam A and Immanuel G: Pharmacological importance of sulphated polysaccharide carrageenan from red seaweed kappaphycus alvarezii in comparison with commercial carrageenan. Biomed Pharmacother 84: 1300-1312, 2016. PMID: 27810787. DOI: 10.1016/j.biopha.2016.10.067

31 Ariffin SH, Yeen WW, Abidin IZ, Abdul Wahab RM, Ariffin ZZ and Senafi S: Cytotoxicity effect of degraded and undegraded kappa and iota carrageenan in human intestine and liver cell lines. BMC Complement Altern Med 14: 508, 2014. PMID: 25519220. DOI: $10.1186 / 1472-6882-14-508$

32 Jazzara M, Ghannam A, Soukkarieh C and Murad H: Antiproliferative activity of lambda-carrageenan through the induction of apoptosis in human breast cancer cells. Iran J Cancer Prev 9(4): e3836, 2016. PMID: 27761203. DOI: $10.17795 /$ ijcp-3836

33 Luo M, Shao B, Nie W, Wei XW, Li YL, Wang BL, He ZY, Liang X, Ye TH and Wei YQ: Antitumor and adjuvant activity of lambda-carrageenan by stimulating immune response in cancer immunotherapy. Sci Rep 5: 11062, 2015. PMID: 26098663. DOI: $10.1038 /$ srep11062

34 Murad H, Ghannam A, Al-Ktaifani M, Abbas A and Hawat M: Algal sulfated carrageenan inhibits proliferation of mda-mb-231 cells via apoptosis regulatory genes. Mol Med Rep 11(3): 21532158, 2015. PMID: 25384757. DOI: 10.3892/mmr.2014.2915

35 Somasundaram SN, Shanmugam S, Subramanian B and Jaganathan R: Cytotoxic effect of fucoidan extracted from sargassum cinereum on colon cancer cell line het-15. Int J Biol Macromol 91: 1215-1223, 2016. PMID: 27370748. DOI: 10.1016/j.ijbiomac.2016.06.084

36 Yun CW, Yun S, Lee JH, Han YS, Yoon YM, An D and Lee SH: Silencing prion protein in ht 29 human colorectal cancer cells enhances anticancer response to fucoidan. Anticancer Res 36(9): 4449-4458, 2016. PMID: 27630281. DOI: 10.21873/ anticanres.10989

37 Xue M, Ji X, Xue C, Liang H, Ge Y, He X, Zhang L, Bian K and Zhang L: Caspase-dependent and caspase-independent induction of apoptosis in breast cancer by fucoidan via the pi3k/akt/gsk3beta pathway in vivo and in vitro. Biomed Pharmacother 94: 898-908, 2017. PMID: 28810530. DOI: 10.1016/j.biopha.2017.08.013

38 Rui X, Pan HF, Shao SL and Xu XM: Anti-tumor and antiangiogenic effects of fucoidan on prostate cancer: Possible jakstat3 pathway. BMC Complement Altern Med 17(1): 378, 2017 PMID: 28764703. DOI: 10.1186/s12906-017-1885-y

39 He X, Xue M, Jiang S, Li W, Yu J and Xiang S: Fucoidan promotes apoptosis and inhibits emt of breast cancer cells. Biol Pharm Bull 42(3): 442-447, 2019. PMID: 30828076. DOI: 10.1248/bpb.b18-00777

40 Hsu HY, Lin TY, Lu MK, Leng PJ, Tsao SM and Wu YC: Fucoidan induces toll-like receptor 4-regulated reactive oxygen species and promotes endoplasmic reticulum stress-mediated apoptosis in lung cancer. Sci Rep 7: 44990, 2017. PMID: 28332554. DOI: $10.1038 /$ srep44990

41 Deepika MS, Thangam R, Sheena TS, Sasirekha R, Sivasubramanian S, Babu MD, Jeganathan $\mathrm{K}$ and
Thirumurugan R: A novel rutin-fucoidan complex based phytotherapy for cervical cancer through achieving enhanced bioavailability and cancer cell apoptosis. Biomed Pharmacother 109: 1181-1195, 2019. PMID: 30551368. DOI: 10.1016/j.jfda. 2015.07.002

42 Jang B, Moorthy MS, Manivasagan P, Xu L, Song K, Lee KD, Kwak M, Oh J and Jin JO: Fucoidan-coated cus nanoparticles for chemo-and photothermal therapy against cancer. Oncotarget 9(16): 12649-12661, 2018. PMID: 29560098. DOI: 10.18632/ oncotarget. 23898

43 Ivanova V, Rouseva R, Kolarova M, Serkedjieva J, Rachev R and Manolova N: Isolation of a polysaccharide with antiviral effect from ulva lactuca. Prep Biochem 24(2): 83-97, 1994. PMID: 8072958.

44 Wang R, Paul VJ and Luesch H: Seaweed extracts and unsaturated fatty acid constituents from the green alga ulva lactuca as activators of the cytoprotective nrf2-are pathway. Free Radic Biol Med 57: 141-153, 2013. PMID: 23291594. DOI: $10.1016 /$ j.freeradbiomed.2012.12.019

45 de Araujo IW, Rodrigues JA, Quindere AL, Silva JF, Maciel GF, Ribeiro NA, de Sousa Oliveira Vanderlei E, Ribeiro KA, Chaves HV, Pereira KM, Bezerra MM and Benevides NM: Analgesic and anti-inflammatory actions on bradykinin route of a polysulfated fraction from alga ulva lactuca. Int $\mathrm{J}$ Biol Macromol 92: 820-830, 2016. PMID: 27481342. DOI: 10.1016/j.ijbiomac.2016.07.094

46 Adrien A, Dufour D, Baudouin S, Maugard T and Bridiau N: Evaluation of the anticoagulant potential of polysaccharide-rich fractions extracted from macroalgae. Nat Prod Res 31(18): 2126-2136, 2017. PMID: 28147712. DOI: 10.1080/147864 19.2017.1278595

47 Abd-Ellatef GF, Ahmed OM, Abdel-Reheim ES and AbdelHamid AZ: Ulva lactuca polysaccharides prevent wistar rat breast carcinogenesis through the augmentation of apoptosis, enhancement of antioxidant defense system, and suppression of inflammation. Breast Cancer (Dove Med Press) 9: 67-83, 2017. PMID: 28280387. DOI: 10.2147/BCTT.S125165

48 Thanh TT, Quach TM, Nguyen TN, Vu Luong D, Bui ML and Tran TT: Structure and cytotoxic activity of ulvan extracted from green seaweed ulva lactuca. Int J Biol Macromol 93(Pt A): 695-702, 2016. PMID: 27637450 . DOI: 10.1016/j.ijbiomac. 6.09 .040

49 Hussein UK, Mahmoud HM, Farrag AG and Bishayee A: Chemoprevention of diethylnitrosamine-initiated and phenobarbital-promoted hepatocarcinogenesis in rats by sulfated polysaccharides and aqueous extract of ulva lactuca. Integr Cancer Ther 14(6): 525-545, 2015. PMID: 26130745. DOI: $10.1177 / 1534735415590157$

50 Bordbar S, Anwar F and Saari N: High-value components and bioactives from sea cucumbers for functional foods--a review. Mar Drugs 9(10): 1761-1805, 2011. PMID: 22072996. DOI: 10.3390/md9101761

51 Aminin DL, Menchinskaya ES, Pisliagin EA, Silchenko AS, Avilov SA and Kalinin VI: Anticancer activity of sea cucumber triterpene glycosides. Mar Drugs 13(3): 1202-1223, 2015. PMID: 25756523. DOI: $10.3390 / \mathrm{md} 13031202$

52 Bahrami Y, Zhang W, Chataway T and Franco C: Structure elucidation of five novel isomeric saponins from the viscera of the sea cucumber holothuria lessoni. Mar Drugs 12(8): 44394473, 2014. PMID: 25110919. DOI: 10.3390/md12084439 
53 Bahrami Y, Zhang W and Franco C: Discovery of novel saponins from the viscera of the sea cucumber holothuria lessoni. Mar Drugs 12(5): 2633-2667, 2014. PMID: 24821624. DOI: $10.3390 / \mathrm{md} 12052633$

54 Atashrazm F, Lowenthal RM, Woods GM, Holloway AF and Dickinson JL: Fucoidan and cancer: A multifunctional molecule with anti-tumor potential. Mar Drugs 13(4): 2327-2346, 2015 PMID: 25874926. DOI: 10.3390/md13042327

55 Sugawara T, Zaima N, Yamamoto A, Sakai S, Noguchi R and Hirata T: Isolation of sphingoid bases of sea cucumber cerebrosides and their cytotoxicity against human colon cancer cells. Biosci Biotechnol Biochem 70(12): 2906-2912, 2006. PMID: 17151482 . DOI: $10.1271 / \mathrm{bbb} .60318$

56 Li X, Roginsky AB, Ding XZ, Woodward C, Collin P, Newman RA, Bell RH Jr. and Adrian TE: Review of the apoptosis pathways in pancreatic cancer and the anti-apoptotic effects of the novel sea cucumber compound, frondoside a. Ann NY Acad Sci 1138: 181-198, 2008. PMID: 18837899. DOI: 10.1196/annals.1414.025

57 Al Marzouqi N, Iratni R, Nemmar A, Arafat K, Ahmed Al Sultan M, Yasin J, Collin P, Mester J, Adrian TE and Attoub S: Frondoside a inhibits human breast cancer cell survival, migration, invasion and the growth of breast tumor xenografts. Eur J Pharmacol 668(1-2): 25-34, 2011. PMID: 21741966. DOI: 10.1016/j.ejphar.2011.06.023

58 Attoub S, Arafat K, Khalaf T, Sulaiman S and Iratni R: Frondoside a enhances the anti-cancer effects of oxaliplatin and 5-fluorouracil on colon cancer cells. Nutrients 10(5), 2018. PMID: 29724012. DOI: 10.3390/nu10050560

59 Dyshlovoy SA, Menchinskaya ES, Venz S, Rast S, Amann K, Hauschild J, Otte K, Kalinin VI, Silchenko AS, Avilov SA, Alsdorf W, Madanchi R, Bokemeyer C, Schumacher U, Walther $\mathrm{R}$, Aminin DL, Fedorov SN, Shubina LK, Stonik VA, Balabanov S, Honecker F and von Amsberg G: The marine triterpene glycoside frondoside a exhibits activity in vitro and in vivo in prostate cancer. Int J Cancer 138(10): 2450-2465, 2016. PMID: 26695519. DOI: 10.1002/ijc.29977

60 Dyshlovoy SA, Madanchi R, Hauschild J, Otte K, Alsdorf WH, Schumacher U, Kalinin VI, Silchenko AS, Avilov SA, Honecker F, Stonik VA, Bokemeyer C and von Amsberg G: The marine triterpene glycoside frondoside a induces p53independent apoptosis and inhibits autophagy in urothelial carcinoma cells. BMC Cancer 17(1): 93, 2017. PMID: 28143426. DOI: $10.1186 / \mathrm{s} 12885-017-3085-\mathrm{z}$

61 Menchinskaya ES, Pislyagin EA, Kovalchyk SN, Davydova VN, Silchenko AS, Avilov SA, Kalinin VI and Aminin DL: Antitumor activity of cucumarioside a2-2. Chemotherapy 59(3): 181-191, 2013. PMID: 24217558. DOI: 10.1159/000354156

62 Menchinskaya ES, Aminin DL, Avilov SA, Silchenko AS, Andryjashchenko PV, Kalinin VI and Stonik VA: Inhibition of tumor cells multidrug resistance by cucumarioside a2-2, frondoside a and their complexes with cholesterol. Nat Prod Commun 8(10): 1377-1380, 2013. PMID: 24354179.

63 Zhao Q, Xue Y, Wang JF, Li H, Long TT, Li Z, Wang YM, Dong $\mathrm{P}$ and Xue $\mathrm{CH}$ : In vitro and in vivo anti-tumour activities of echinoside a and ds-echinoside a from pearsonothuria graeffei. J Sci Food Agric 92(4): 965-974, 2012. PMID: 22012678. DOI: $10.1002 /$ jsfa.4678

64 Wargasetia TL, Permana S and Widodo N: Potential use of compounds from sea cucumbers as mdm2 and cxcr4 inhibitors to control cancer cell growth. Exp Ther Med 16(4): 2985-2991, 2018. PMID: 30250516. DOI: 10.3892/etm.2018.6588

65 Zhao Q, Liu ZD, Xue Y, Wang JF, Li H, Tang QJ, Wang YM, Dong $\mathrm{P}$ and Xue $\mathrm{CH}$ : Ds-echinoside a, a new triterpene glycoside derived from sea cucumber, exhibits antimetastatic activity via the inhibition of nf-kappab-dependent mmp-9 and vegf expressions. J Zhejiang Univ Sci B 12(7): 534-544, 2011. PMID: 21726060. DOI: 10.1631/jzus.B1000217

66 Janakiram NB, Mohammed A, Zhang Y, Choi CI, Woodward C, Collin P, Steele VE and Rao CV: Chemopreventive effects of frondanol a5, a cucumaria frondosa extract, against rat colon carcinogenesis and inhibition of human colon cancer cell growth. Cancer Prev Res (Phila) 3(1): 82-91, 2010. PMID: 20051375. DOI: 10.1158/1940-6207.CAPR-09-0112

67 Janakiram NB, Mohammed A, Bryant T, Lightfoot S, Collin $\mathrm{PD}$, Steele VE and Rao CV: Improved innate immune responses by frondanol a5, a sea cucumber extract, prevent intestinal tumorigenesis. Cancer Prev Res (Phila) 8(4): 327-337, 2015. PMID: 25657017. DOI: 10.1158/1940-6207.CAPR-14-0380

68 Roginsky AB, Ding XZ, Woodward C, Ujiki MB, Singh B, Bell $\mathrm{RH}$ Jr., Collin P and Adrian TE: Anti-pancreatic cancer effects of a polar extract from the edible sea cucumber, cucumaria frondosa. Pancreas 39(5): 646-652, 2010. PMID: 20124937. DOI: 10.1097/MPA.0b013e3181c72baf

69 Tong Y, Zhang X, Tian F, Yi Y, Xu Q, Li L, Tong L, Lin L and Ding J: Philinopside a, a novel marine-derived compound possessing dual anti-angiogenic and anti-tumor effects. Int $\mathbf{J}$ Cancer 114(6): 843-853, 2005. PMID: 15645493. DOI: 10.1002/ijc.20804

70 Tian F, Zhu CH, Zhang XW, Xie X, Xin XL, Yi YH, Lin LP, Geng MY and Ding J: Philinopside e, a new sulfated saponin from sea cucumber, blocks the interaction between kinase insert domain-containing receptor $(\mathrm{kdr})$ and alphavbeta 3 integrin via binding to the extracellular domain of kdr. Mol Pharmacol 72(3): 545-552, 2007. PMID: 17565003. DOI: 10.1124/mol.107.036350

71 Dong G, Xu T, Yang B, Lin X, Zhou X, Yang X and Liu Y: Chemical constituents and bioactivities of starfish. Chem Biodivers 8(5): 740-791, 2011. PMID: 21560228. DOI: 10.1002/cbdv.200900344

72 Ivanchina NV, Kicha AA and Stonik VA: Steroid glycosides from marine organisms. Steroids 76(5): 425-454, 2011. PMID: 21194537. DOI: 10.1016/j.steroids.2010.12.011

73 Minale L, Riccio R and Zollo F: Steroidal oligoglycosides and polyhydroxysteroids from echinoderms. Fortschr Chem Org Naturst 62: 75-308, 1993. PMID: 8349219.

74 Ngoan BT, Hanh TT, Vien le T, Diep CN, Thao NP, Thao do T, Thanh NV, Cuong NX, Nam NH, Thung do C, Kiem PV, Kim YH and Minh CV: Asterosaponins and glycosylated polyhydroxysteroids from the starfish culcita novaeguineae and their cytotoxic activities. J Asian Nat Prod Res 17(10): 1010-1017, 2015. PMID: 26001122. DOI: 10.1080/10286020.2015.1041930

75 Kicha AA, Ha DT, Ivanchina NV, Malyarenko TV, Kalinovsky AI, Dmitrenok PS, Ermakova SP, Malyarenko OS, Hung NA, Thuy TTT and Long PQ: Six new polyhydroxysteroidal glycosides, anthenosides s1 - s6, from the starfish anthenea sibogae. Chem Biodivers 15(3): e1700553, 2018. PMID: 29356326. DOI: $10.1002 /$ cbdv.201700553

76 Lee CC, Hsieh HJ, Hsieh CH and Hwang DF: Plancitoxin i from the venom of crown-of-thorns starfish (acanthaster planci) induces oxidative and endoplasmic reticulum stress associated 
cytotoxicity in a375.S2 cells. Exp Mol Pathol 99(1): 7-15 2015. PMID: 25952364. DOI: 10.1016/j.yexmp.2015.05.001

77 Lee CC, Hsieh HJ and Hwang DF: Cytotoxic and apoptotic activities of the plancitoxin $i$ from the venom of crown-ofthorns starfish (acanthaster planci) on a375.S2 cells. J Appl Toxicol 35(4): 407-417, 2015. PMID: 25047904. DOI: $10.1002 /$ jat.3034

78 Malyarenko OS, Dyshlovoy SA, Kicha AA, Ivanchina NV, Malyarenko TV, Carsten B, Gunhild VA, Stonik VA and Ermakova SP: The inhibitory activity of luzonicosides from the starfish echinaster luzonicus against human melanoma cells Mar Drugs 15(7), 2017. PMID: 28718806. DOI: 10.3390/md1 5070227

79 Harasewych MG: Pleurotomarioidean gastropods. Adv Mar Biol 42: 237-294, 2002. PMID: 12094724.

80 Thao NP, Luyen BT, Kim EJ, Kang JI, Kang HK, Cuong NX, Nam NH, Kiem PV, Minh CV and Kim YH: Steroidal constituents from the edible sea urchin diadema savignyi michelin induce apoptosis in human cancer cells. J Med Food 18(1): 4553, 2015. PMID: 25211186. DOI: 10.1089/jmf.2013.3105

81 Russo GL, Russo M, Castellano I, Napolitano A and Palumbo A: Ovothiol isolated from sea urchin oocytes induces autophagy in the hep-g2 cell line. Mar Drugs 12(7): 4069-4085, 2014. PMID: 25003791. DOI: 10.3390/md12074069

82 Liu C, Xi T, Lin Q, Xing Y, Ye L, Luo X and Wang F: Immunomodulatory activity of polysaccharides isolated from strongylocentrotus nudus eggs. Int Immunopharmacol 8(13-14): 1835-1841, 2008. PMID: 18834960. DOI: 10.1016/j.intimp.2008. 09.005

83 Sahara H, Ishikawa M, Takahashi N, Ohtani S, Sato N, Gasa S, Akino $\mathrm{T}$ and Kikuchi K: In vivo anti-tumour effect of 3'sulphonoquinovosyl 1'-monoacylglyceride isolated from sea urchin (strongylocentrotus intermedius) intestine. Br J Cancer 75(3): 324-332, 1997. PMID: 9020475. DOI: 10.1038/bjc. 1997.54

84 Mehbub MF, Lei J, Franco C and Zhang W: Marine sponge derived natural products between 2001 and 2010: Trends and opportunities for discovery of bioactives. Mar Drugs 12(8): 45394577, 2014. PMID: 25196730. DOI: 10.3390/md12084539

85 Essack M, Bajic VB and Archer JA: Recently confirmed apoptosis-inducing lead compounds isolated from marine sponge of potential relevance in cancer treatment. Mar Drugs 9(9): 1580-1606, 2011. PMID: 22131960. DOI: 10.3390/ md9091580

86 Calcabrini C, Catanzaro E, Bishayee A, Turrini E and Fimognari C: Marine sponge natural products with anticancer potential: An updated review. Mar Drugs 15(10), 2017. PMID: 29027954. DOI: 10.3390/md15100310

87 Gordon EM, Sankhala KK, Chawla N and Chawla SP: Trabectedin for soft tissue sarcoma: Current status and future perspectives. Adv Ther 33(7): 1055-1071, 2016. PMID: 27234989. DOI: $10.1007 / \mathrm{s} 12325-016-0344-3$

88 Tabunoki H, Saito N, Suwanborirux K, Charupant K and Satoh $\mathrm{J}$ : Molecular network profiling of u373mg human glioblastoma cells following induction of apoptosis by novel marine-derived anti-cancer 1,2,3,4-tetrahydroisoquinoline alkaloids. Cancer Cell Int 12(1): 14, 2012. PMID: 22494416. DOI: 10.1186/14752867-12-14

89 Charupant K, Daikuhara N, Saito E, Amnuoypol S, Suwanborirux K, Owa T and Saito N: Chemistry of renieramycins. Part 8:
Synthesis and cytotoxicity evaluation of renieramycin mjorunnamycin a analogues. Bioorg Med Chem 17(13): 4548-4558, 2009. PMID: 19457672. DOI: 10.1016/j.bmc.2009.05.009

90 Sirimangkalakitti N, Chamni S, Suwanborirux K and Chanvorachote P: Renieramycin $\mathrm{m}$ attenuates cancer stem cell-like phenotypes in h460 lung cancer cells. Anticancer Res 37(2): 615621, 2017. PMID: 28179308. DOI: 10.21873/anticanres.11355

91 Sirimangkalakitti N, Chamni S, Suwanborirux K and Chanvorachote P: Renieramycin $\mathrm{m}$ sensitizes anoikis-resistant h460 lung cancer cells to anoikis. Anticancer Res 36(4): 16651671, 2016. PMID: 27069144.

92 Maiuthed A, Pinkhien T, Chamni S, Suwanborirux K, Saito N, Petpiroon $\mathrm{N}$ and Chanvorachote P: Apoptosis-inducing effect of hydroquinone 5-o-cinnamoyl ester analog of renieramycin $\mathrm{m}$ on non-small cell lung cancer cells. Anticancer Res 37(11): 62596267, 2017. PMID: 29061809. DOI: 10.21873/anticanres.12077

93 Pinkhien T, Maiuthed A, Chamni S, Suwanborirux K, Saito N and Chanvorachote $\mathrm{P}$ : Bishydroquinone renieramycin $\mathrm{m}$ induces apoptosis of human lung cancer cells through a mitochondria-dependent pathway. Anticancer Res 36(12): 63276333, 2016. PMID: 27919953. DOI: 10.21873/anticanres.11229

94 Newman DJ, Cragg GM and Snader KM: The influence of natural products upon drug discovery. Nat Prod Rep 17(3): 215234, 2000. PMID: 10888010.

95 Jimenez PC, Wilke DV and Costa-Lotufo LV: Marine drugs for cancer: Surfacing biotechnological innovations from the oceans. Clinics (Sao Paulo) 73(suppl 1): e482s, 2018. PMID: 30133563. DOI: $10.6061 /$ clinics/2018/e482s

96 Konig GM and Wright AD: Laurencia rigida: Chemical investigations of its antifouling dichloromethane extract. J Nat Prod 60(10): 967-970, 1997. PMID: 9358636. DOI: 10.1021/ np970181r

97 Schwartsmann G, Brondani da Rocha A, Berlinck RG and Jimeno J: Marine organisms as a source of new anticancer agents. Lancet Oncol 2(4): 221-225, 2001. PMID: 11905767.

98 de Vries JF, Falkenburg JH, Willemze R and Barge RM: The mechanisms of ara-c-induced apoptosis of resting b-chronic lymphocytic leukemia cells. Haematologica 91(7): 912-919, 2006. PMID: 16818278.

99 Chen L, Guo P, Zhang Y, Li X, Jia P, Tong J and Li J: Autophagy is an important event for low-dose cytarabine treatment in acute myeloid leukemia cells. Leuk Res 60: 44-52, 2017. PMID: 28651104. DOI: 10.1016/j.leukres.2017.06.007

100 Leal JF, Garcia-Hernandez V, Moneo V, Domingo A, BuerenCalabuig JA, Negri A, Gago F, Guillen-Navarro MJ, Aviles P, Cuevas C, Garcia-Fernandez LF and Galmarini CM: Molecular pharmacology and antitumor activity of zalypsis in several human cancer cell lines. Biochem Pharmacol 78(2): 162-170, 2009. PMID: 19427997. DOI: 10.1016/j.bcp.2009.04.003

101 Colado E, Paino T, Maiso P, Ocio EM, Chen X, AlvarezFernandez S, Gutierrez NC, Martin-Sanchez J, Flores-Montero J, San Segundo L, Garayoa M, Fernandez-Lazaro D, Vidriales MB, Galmarini CM, Aviles P, Cuevas C, Pandiella A and SanMiguel JF: Zalypsis has in vitro activity in acute myeloid blasts and leukemic progenitor cells through the induction of a DNA damage response. Haematologica 96(5): 687-695, 2011. PMID: 21330323. DOI: $10.3324 /$ haematol.2010.036400

102 Ro J, Cheng FT, Sriuranpong V, Villalon A, Smruti BK, Tsang J, Yap YS and Asian Working Group for Eribulin Clinical G: Patient management with eribulin in metastatic breast cancer: 
A clinical practice guide. J Breast Cancer 19(1): 8-17, 2016. PMID: 27066091. DOI: 10.4048/jbc.2016.19.1.8

103 Towle MJ, Salvato KA, Wels BF, Aalfs KK, Zheng W, Seletsky BM, Zhu X, Lewis BM, Kishi Y, Yu MJ and Littlefield BA: Eribulin induces irreversible mitotic blockade: Implications of cell-based pharmacodynamics for in vivo efficacy under intermittent dosing conditions. Cancer Res 71(2): 496-505, 2011. PMID: 21127197. DOI: 10.1158/0008-5472.CAN-101874

104 Steinestel K, Eder S, Schrader AJ and Steinestel J: Clinical significance of epithelial-mesenchymal transition. Clin Transl Med 3: 17, 2014. PMID: 25050175. DOI: 10.1186/2001-13263-17

105 Towle MJ, Salvato KA, Budrow J, Wels BF, Kuznetsov G, Aalfs KK, Welsh S, Zheng W, Seletsky BM, Palme MH, Habgood GJ, Singer LA, Dipietro LV, Wang Y, Chen JJ, Quincy DA, Davis A, Yoshimatsu K, Kishi Y, Yu MJ and Littlefield BA: In vitro and in vivo anticancer activities of synthetic macrocyclic ketone analogues of halichondrin b. Cancer Res 61(3): 1013-1021, 2001. PMID: 11221827.

106 Kolb EA, Gorlick R, Reynolds CP, Kang MH, Carol H, Lock R, Keir ST, Maris JM, Billups CA, Desjardins C, Kurmasheva RT, Houghton PJ and Smith MA: Initial testing (stage 1) of eribulin, a novel tubulin binding agent, by the pediatric preclinical testing program. Pediatr Blood Cancer 60(8): 13251332, 2013. PMID: 23553917. DOI: 10.1002/pbc.24517

107 Towle MJ, Nomoto K, Asano M, Kishi Y, Yu MJ and Littlefield BA: Broad spectrum preclinical antitumor activity of eribulin (halaven(r)): Optimal effectiveness under intermittent dosing conditions. Anticancer Res 32(5): 1611-1619, 2012. PMID: 22593439.

108 Kaufman PA, Awada A, Twelves C, Yelle L, Perez EA, Velikova G, Olivo MS, He Y, Dutcus CE and Cortes J: Phase iii open-label randomized study of eribulin mesylate versus capecitabine in patients with locally advanced or metastatic breast cancer previously treated with an anthracycline and a taxane. J Clin Oncol 33(6): 594-601, 2015. PMID: 25605862. DOI: $10.1200 / J C O .2013 .52 .4892$

109 Anderson HJ, Coleman JE, Andersen RJ and Roberge M: Cytotoxic peptides hemiasterlin, hemiasterlin a and hemiasterlin $\mathrm{b}$ induce mitotic arrest and abnormal spindle formation. Cancer Chemother Pharmacol 39(3): 223-226, 1997. PMID: 8996524.
110 Bai R, Durso NA, Sackett DL and Hamel E: Interactions of the sponge-derived antimitotic tripeptide hemiasterlin with tubulin: Comparison with dolastatin 10 and cryptophycin 1 . Biochemistry 38(43): 14302-14310, 1999. PMID: 10572005. DOI: $10.1021 /$ bi991323e

111 Kuznetsov G, TenDyke K, Towle MJ, Cheng H, Liu J, Marsh JP, Schiller SE, Spyvee MR, Yang H, Seletsky BM, Shaffer CJ, Marceau V, Yao Y, Suh EM, Campagna S, Fang FG, Kowalczyk $\mathrm{JJ}$ and Littlefield BA: Tubulin-based antimitotic mechanism of e7974, a novel analogue of the marine sponge natural product hemiasterlin. Mol Cancer Ther 8(10): 2852-2860, 2009. PMID: 19825803. DOI: 10.1158/1535-7163.MCT-09-0301

112 Cuevas C and Francesch A: Development of yondelis (trabectedin, et-743). A semisynthetic process solves the supply problem. Nat Prod Rep 26(3): 322-337, 2009. PMID: 19240944. DOI: $10.1039 / \mathrm{b} 808331 \mathrm{~m}$

113 Kasper B, Reichardt P, Pink D, Sommer M, Mathew M, Rauch $\mathrm{G}$ and Hohenberger P: Combination of trabectedin and gemcitabine for advanced soft tissue sarcomas: Results of a phase $\mathrm{i}$ dose escalating trial of the german interdisciplinary sarcoma group (gisg). Mar Drugs 13(1): 379-388, 2015. PMID: 2559104. DOI: $10.3390 / \mathrm{md} 13010379$

114 Blay JY, von Mehren M, Samuels BL, Fanucchi MP, RayCoquard I, Buckley B, Gilles L, Lebedinsky C, Elsayed YA and Le Cesne A: Phase i combination study of trabectedin and doxorubicin in patients with soft-tissue sarcoma. Clin Cancer Res 14(20): 6656-6662, 2008. PMID: 18927308. DOI: 10.1158/1078-0432.CCR-08-0336

115 Krasner CN, Poveda A, Herzog TJ, Vermorken JB, Kaye SB, Nieto A, Claret PL, Park YC, Parekh T and Monk BJ: Patient-reported outcomes in relapsed ovarian cancer: Results from a randomized phase iii study of trabectedin with pegylated liposomal doxorubicin (pld) versus pld alone. Gynecol Oncol 127(1): 161-167, 2012. PMID: 22765965. DOI: 10.1016/j.ygyno.2012.06.034

Received August 1, 2019

Revised August 20, 2019

Accepted August 21, 2019 